\title{
THE FACE OF BATTLE? DEBATING ARROW TRAUMA ON MEDIEVAL HUMAN REMAINS FROM PRINCESSHAY, EXETER
}

\author{
Oliver H Creighton, FSA, Laura Evis, Mandy Kingdom, Catriona J McKenzie, \\ Iain Watt and Alan K Outram, FSA
}

Oliver H Creighton, Department of Archaeology, Laver Building, North Park Road, Exeter, Devon EX4 4QE, UK. Email: O.H.Creighton@exeter.ac.uk

Laura Evis, Department of Archaeology, Laver Building, North Park Road, Exeter, Devon EX4 4QE, UK. Email: L.Evis@exeter.ac.uk

Mandy Kingdom, Department of Archaeology, Laver Building, North Park Road, Exeter, Devon EX4 4QE, UK. Email: M.J.Kingdom@exeter.ac.uk

Catriona J McKenzie, Department of Archaeology, Laver Building, North Park Road, Exeter, Devon EX4 4QE, UK. Email: C.Mckenzie@exeter.ac.uk

Iain Watt, Department of Archaeology, Laver Building, North Park Road, Exeter, Devon EX4 4QE, UK. Email: I.Watt@exeter.ac.uk

Alan K Outram, Department of Archaeology, Laver Building, North Park Road, Exeter, Devon EX4 4QE, UK. Email: A.K.Outram@exeter.ac.uk

Physical evidence of weapon trauma in medieval burials is unusual, and evidence for trauma caused by arrowheads is exceptionally rare. Where high frequencies of traumatic injuries have been identified, this is mainly in contexts related to battles; it is much less common in normative burials. Osteological analysis of one context from an assemblage of disarticulated and commingled human bones recovered from a cemetery associated with the thirteenth-century Dominican friary in Exeter, Devon, shows several instances of weapon trauma, including multiple injuries caused by projectile points. Arrow trauma is notoriously difficult to identify, but this assemblage shows that arrows fired from longbows could result in entry and exit wounds in the skull not incomparable to modern gunshot wounds. Microscopic examination of the fracture patterns and spalling associated with these puncture wounds provides tentative evidence that medieval arrows were fletched to spin clockwise. These results have profound implications for our understanding of the power of the medieval longbow, for how we recognise arrow trauma in the archaeological record and for our knowledge of how common violent death and injury were in the medieval past, and how and where casualties were buried.

Key words: arrows; arrowheads; trauma; human remains; conflict; osteoarchaeology

\section{INTRODUCTION}

The study of interpersonal violence in the past, and the recognition of its physical traces on human remains, are issues of universal significance to archaeologists working in different research contexts around the world, ${ }^{\mathrm{I}}$ just as they are to forensic scientists

I. Frayer and Martin 1997; Knüsel and Smith 2013; Redfern 2017. 
working today. Direct evidence of violent encounters in the form of traumatic injuries to skeletal remains caused by weapons is relatively rare in medieval burials. In a review of published literature, Roberts and Cox calculated that approximately 2.12 per cent (133/6283) of skeletons (from various sites dating to the later medieval period) were affected by cranial trauma caused by weapon injuries, and approximately 2.29 per cent (2I/9I6) were affected by post-cranial weapon injuries. ${ }^{2}$ Where high frequencies of injuries are recognised, this is mainly in the context of mass burials from known battles and has received detailed discussion. Such data provide a valuable corrective to studies of contemporary warfare based predominantly on the documentary sources and has enormous potential to inform us about the realities of medieval warfare - how people fought and were killed, which weapons were used and what sorts of injuries these caused, and what armour (if any) was worn. ${ }^{3}$ Two classic case studies of mass battle casualty burials are the key points of reference: from the Battle of Visby (in Gotland, Sweden) in $\mathrm{AD}$ I36I, ${ }^{4}$ and Towton (in North Yorkshire, England), fought exactly a century later in $\mathrm{AD}$ I46I. ${ }^{5}$

High frequencies of traumatic injuries in normative burial contexts (that is, not from known mass graves related to battles) are more difficult to explain. This paper presents an osteological analysis of one context (EPHo6 8849) from an assemblage of disarticulated and commingled human bones that shows an unusual concentration of different sorts of traumatic injuries. This dataset is used as a platform for a broader debate about methodological issues around identifying interpersonal violence in the archaeological record and, specifically, about recognising injuries caused by arrowheads.

\section{THE HUMAN REMAINS FROM PRINCESSHAY}

The skeletal assemblage discussed in this paper was recovered during the large-scale excavations conducted by Exeter Archaeology during 1997 to 2007 in advance of the construction of the Princesshay shopping precinct in Exeter city centre (figs I-2). ${ }^{6}$ The excavations investigated part of the church and precinct of the medieval Dominican friary, and the human remains were derived from its burial ground. The friary was established in I232 and consecrated by Bishop Bronescombe in I259. ${ }^{7}$ It lay, typically for a friary, on the urban fringes, on Bedford Street, north-east of the cathedral and immediately within the line of the city walls. The friars acquired a cemetery shortly after the consecration of the friary; their disputes with Exeter cathedral about burial rights are recorded towards the end of the thirteenth century, when it is clear that members of the laity, including wealthy individuals, were buried in the friary cemetery. ${ }^{8}$

The human remains in question derived from context EPHo6 8849, which was situated in the north aisle of the friary nave. This context comprised redeposited grave fill from

2. Roberts and Cox 2003, 275.

3. Knüsel 2005 and 2013; Knüsel and Boylston 2000.

4. Thordman et al $200 \mathrm{I}$.

5. Fiorato et al 2000; Holst and Sutherland 20I4.

6. Steinmetzer et al forthcoming.

7. Lepine and Orme 2003, 9-13.

8. Steinmetzer et al forthcoming. 


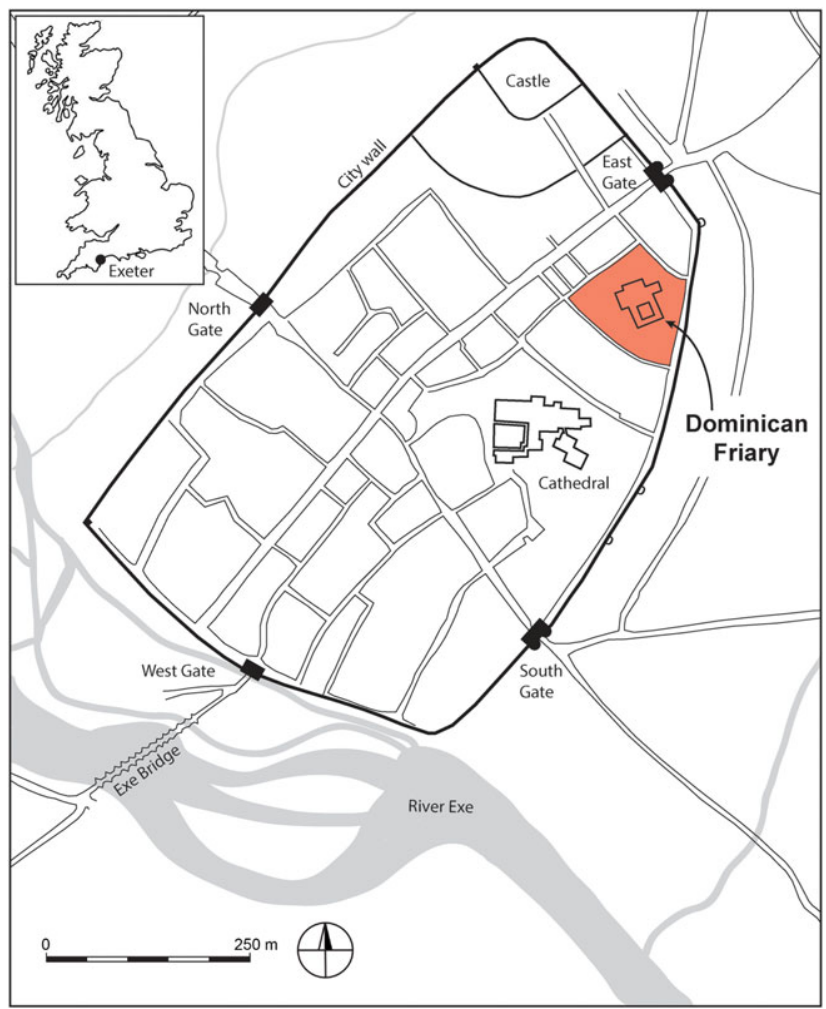

Fig I. Location map, showing the site of Exeter's Dominican friary and the key features of the medieval city. Map: authors.

earlier disturbed burials, and the disarticulated bone was recorded as a grave fill of burial EPHo6 887I, the skeleton of a middle-aged female (approximately 35-50 years of age). That this fill contained disarticulated human remains is not unusual; the intercutting of graves ensured that disarticulated bone was frequently dislodged from the grave fill of intact skeletons. Although we can only speculate on the status of the individuals in question, it is well established that burial within the nave of a friary was popular among high-status members of the laity. ${ }^{9}$

\section{Disarticulated remains from EPH06 8849}

A total of forty-nine adult bones that were greater than 50 per cent complete was recorded from this context (detailed in table I). The bones most commonly represented in the sample were skull bones (12/49), followed by the bones of the lower limb (9/49), upper limb (8/49) and hand (7/49). The bones that were less commonly represented in this sample included the ribs (5/49), bones of the feet $(5 / 49)$ and vertebral bones $(3 / 49)$.

9. Gilchrist and Sloane 2005, 63-4. 
Table 1. List of skeletal elements from context EPH06 8849, which are greater than 50 per cent complete.

\begin{tabular}{|c|c|c|}
\hline Identification code & Skeletal element & Approximate completeness \\
\hline $884901^{\star}$ & Frontal & $75-100 \%$ \\
\hline $884901^{\star}$ & Left Parietal & $75-100 \%$ \\
\hline $884901^{\star}$ & Right Parietal & $75-100 \%$ \\
\hline 884906 & Left Temporal & $75-100 \%$ \\
\hline 884908 & Right Temporal & $75-100 \%$ \\
\hline $884909^{\star}$ & Right Maxilla & $50-75 \%$ \\
\hline $884909^{\star}$ & Left Maxilla & $50-75 \%$ \\
\hline $884909^{\star}$ & Right Nasal & $100 \%$ \\
\hline $884909^{\star}$ & Left Nasal & $100 \%$ \\
\hline 884911 & Left Zygomatic & $>75 \%$ \\
\hline 884921 & Mandible & $50-75 \%$ \\
\hline 884923 & Mandible & $50-75 \%$ \\
\hline 884925 & Right Clavicle & $50-75 \%$ \\
\hline 884940 & Left Radius & $100 \%$ \\
\hline 884941 & Right Radius & $50-75 \%$ \\
\hline 884947 & Right Radius & $50-75 \%$ \\
\hline 884948 & Cervical vertebra 1 & $100 \%$ \\
\hline 884949 & Thoracic vertebra 11 & $100 \%$ \\
\hline 884950 & Thoracic vertebra 12 & $75-100 \%$ \\
\hline 884967 & Left Rib unnumbered & $50-75 \%$ \\
\hline 884968 & Left Rib 2 & $50-75 \%$ \\
\hline 884969 & Right Rib 11 & $75-100 \%$ \\
\hline 884970 & Right Rib 12 & $50-75 \%$ \\
\hline 884977 & Right Rib unnumbered & $50-75 \%$ \\
\hline 884981 & Right Femur & $50-75 \%$ \\
\hline 884983 & Right Femur & $50-75 \%$ \\
\hline 884985 & Left Femur & $50-75 \%$ \\
\hline 884994 & Left Femur & $50-75 \%$ \\
\hline 8849100 & Right Tibia & $100 \%$ \\
\hline 8849101 & Right Tibia & $50-75 \%$ \\
\hline 8849106 & Left Tibia & $50-75 \%$ \\
\hline 8849117 & Right Tibia & $75-100 \%$ \\
\hline 8849120 & Right Patella & $100 \%$ \\
\hline 8849126 & Right Humerus & $50-75 \%$ \\
\hline 8849127 & Left Humerus & $50-75 \%$ \\
\hline 8849129 & Right Humerus & $75-100 \%$ \\
\hline
\end{tabular}

(Continued) 
Table 1. (Continued)

\begin{tabular}{llc}
\hline Identification code & Skeletal element & Approximate completeness \\
\hline 8849131 & Left Ulna & $100 \%$ \\
8849135 & Left 3rd Metacarpal & $75-100 \%$ \\
8849136 & Left 3rd Metacarpal & $75-100 \%$ \\
8849137 & Left 5th Metacarpal & $75-100 \%$ \\
8849138 & Metacarpal unnumbered & $75-100 \%$ \\
8849139 & Metacarpal unnumbered & $75-100 \%$ \\
8849140 & Metacarpal unnumbered & $75-100 \%$ \\
8849141 & Left 3rd Metacarpal & $75-00 \%$ \\
8849142 & Left 1st Metatarsal & $100 \%$ \\
8849143 & Left 2nd Metatarsal & $75-100 \%$ \\
8849144 & Right 2nd Metatarsal & $75-100 \%$ \\
8849145 & Metatarsal unnumbered & $75-100 \%$ \\
8849146 & Metatarsal unnumbered & $75-100 \%$ \\
\hline
\end{tabular}

*Note skeletal elements with the same identification code are fused together.
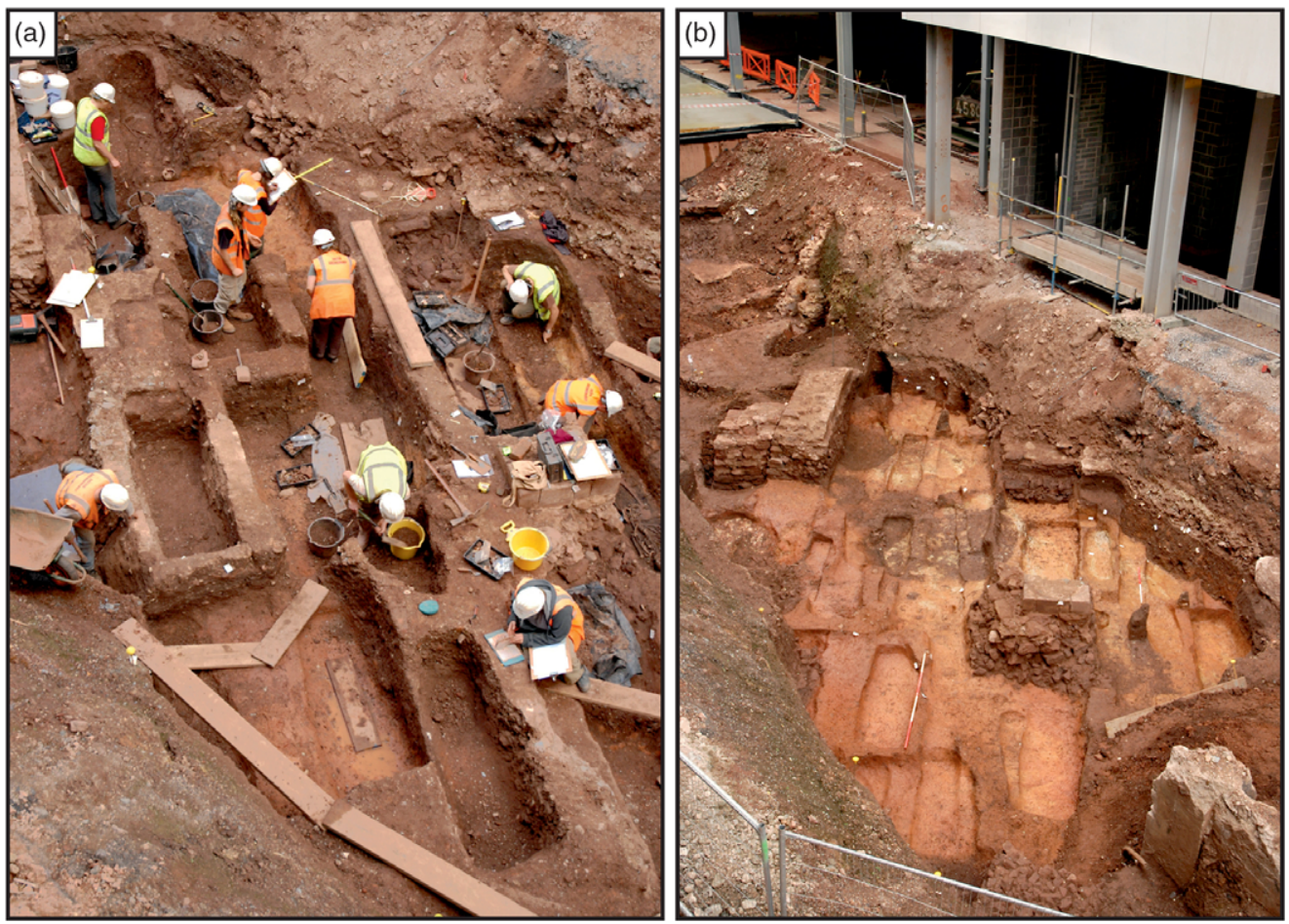

Fig 2. Excavation of burials within Exeter's Dominican friary by Exeter Archaeology, (a) showing excavation in progress and (b) after excavation. Photograph: courtesy of John Allan. 
The most frequently recurring skeletal element in the whole sample was the right proximal femur, of which there were three adult bones present (identification codes 884980, 884982 and 884984). An additional left femoral diaphysis (identification code 884996) was substantially smaller in size, and likely came from an adolescent individual (although the ends of the diaphysis had been broken post mortem, so it was not possible to examine the epiphyses). It is therefore clear that a minimum number of four individuals was represented by human skeletal elements in this context.

Among this small sample of skeletal remains, the most commonly recurring skeletal element that could be used to give an estimation of sex were two mandibles (identification codes 88492 I and 884923). Both bones displayed characteristics of male individuals, with perpendicular and everted gonial angles, broad mandibular rami, and prominent mental protuberances. ${ }^{\text {I0 }}$ The sexually dimorphic characteristics of an almost complete cranium (88490I-8849I4) indicated that these bones were also likely derived from a male individual. These cranial elements were robust, with prominent supraorbital ridges and a prominent glabella region. It is possible that one of the mandibles in the collection originally articulated with the cranial bones, and, as such, in this context the remains of a minimum number of two adults could be sexed as male.

\section{PATHOLOGICAL LESIONS AND TRAUMATIC INJURIES}

A total of thirty bone fragments and four teeth had pathological lesions evident (for full details of these, see table 2). A near complete cranium (88490I-8849I4), a left proximal femur (884986-88499I), a right tibia (8849II7) and a right humerus (884936-884937 and 8849I26) all have traumatic injuries causing peri-mortem radiating fractures. In addition, a left femoral diaphysis (884996) exhibits a traumatic injury without corresponding radiating fractures, and one healed ante-mortem fracture was identified in an unsided rib fragment (884979). This unusual concentration of evidence for skeletal trauma is compiled in table 3 and described in detail below, prior to a consideration of the context and dating of the assemblage, an interpretation of the injuries and an assessment of their significance.

\section{Cranium (identification codes: 884901-884914 (figs 3-8))}

The cranial vault is reasonably intact, although the facial bones are badly fragmented. The maxilla is present for analysis, but the mandible was absent. In the left orbit, a superficial layer of new compact bone formation is evident elevated above the underlying cortex, measuring maximum dimensions of $20.3 \mathrm{~mm}$ antero-posteriorly by $22.7 \mathrm{~mm}$ medio-laterally (fig 3). Compact abnormal bone formation in the orbit may be consistent with the diagnosis of an orbital haematoma, caused by inflammation in this location which could be secondary to a traumatic injury. ${ }^{\text {II }}$ There was no additional evidence on

I0. Ferembach et al 1980.

II. Weston 20I2, 504 . 
Table 2. List of bone fragments from context EPH06 8849, with pathological lesions evident.

\begin{tabular}{|c|c|c|}
\hline $\begin{array}{l}\text { Identification } \\
\operatorname{code}(s)\end{array}$ & Element & Pathological lesion \\
\hline 884901 & Frontal & $\begin{array}{l}\text { Localised reactive woven bone formation } \\
\text { is evident in the left orbital roof }\end{array}$ \\
\hline 884909 & Right maxillary 1st premolar & Carious lesion evident \\
\hline 884910 & Left maxillary 3rd molar & Carious lesion evident \\
\hline 884919 & Right maxillary 1 st molar & Carious lesion evident \\
\hline 884921 & $\begin{array}{l}\text { Left mandibular } 1 \mathrm{st} \\
\text { premolar }\end{array}$ & Large abscess at apex of tooth root \\
\hline 884978 & 17 rib fragments unsided & $\begin{array}{l}\text { Healed periosteal new bone formation } \\
\text { evident on three unsided rib fragments }\end{array}$ \\
\hline 884981 & Right femur & Healed periosteal new bone formation evident \\
\hline 884983 & Right femur & Healed periosteal new bone formation evident \\
\hline $884986-884991$ & Left femur & Healed periosteal new bone formation evident \\
\hline 884993 & Left femur & Healed periosteal new bone formation evident \\
\hline 884994 & Left femur & Healed periosteal new bone formation evident \\
\hline 884995 & Left femur & Healed periosteal new bone formation evident \\
\hline 8849100 & Right tibia & Periosteal new bone formation, mixed reaction \\
\hline 8849101 & Right tibia & Periosteal new bone formation, mixed reaction \\
\hline 8849106 & Left tibia & Periosteal new bone formation, mixed reaction \\
\hline $\begin{array}{l}8849107- \\
8849108\end{array}$ & Left tibia & Periosteal new bone formation, mixed reaction \\
\hline 8849109 & Left tibia & Periosteal new bone formation, mixed reaction \\
\hline 8849111 & Right tibia & Periosteal new bone formation, mixed reaction \\
\hline
\end{tabular}

the cranial bones present to suggest that the orbital haematoma was caused by an underlying pathological process such as anaemia, rickets in childhood, or scurvy. ${ }^{\mathrm{I2}}$

Evidence of trauma is visible in two places in the cranial bones:

1. Positioned over the right orbit is a right-angled puncture on the medial aspect of the supraorbital margin (fig 4). Two sides of this puncture wound survive, with a matching puncture through the right frontal sinus (caused by penetration of the same object). The edges of the puncture closest to the right angle appear to directly represent the cross-section of the impacting implement, with peri-mortem fractures then propagating from the margins of the initial puncture. On the supraorbital margin the penetrating object appears to be of approximately square cross-section with dimensions of at least $5.8 \mathrm{~mm}$ medio-laterally by $5.2 \mathrm{~mm}$ superoinferiorly. Deeper within the cranium, at the frontal sinus the angle produced by the object is closer to $75^{\circ}$ with dimensions of $5.5 \mathrm{~mm}$ medio-laterally by $3.5 \mathrm{~mm}$

I2. Klaus 2014 and 2017. 
Table 3. List of bone fragments from context EPH06 8849, with peri-mortem and ante-mortem injuries.

\begin{tabular}{|c|c|c|}
\hline $\begin{array}{l}\text { Identification } \\
\operatorname{code}(\mathrm{s})\end{array}$ & Element(s) & Injury \\
\hline $884901-884914$ & $\begin{array}{l}\text { Frontal } \\
\text { Left and right parietal } \\
\text { Occipital } \\
\text { Left and right } \\
\text { temporal } \\
\text { Left and right maxilla } \\
\text { Left and right nasal } \\
\text { Left zygomatic } \\
\text { Sphenoid }\end{array}$ & $\begin{array}{l}\text { - Peri-mortem right-angled puncture on the medial } \\
\text { aspect of the right supraorbital margin } \\
\text { - Peri-mortem fracture in the occipital bone }\end{array}$ \\
\hline $\begin{array}{l}884936-884937 \\
8849126\end{array}$ & Right humerus & - Comminuted peri-mortem fracture \\
\hline 884979 & Rib fragment unsided & - Ante-mortem simple, healed fracture \\
\hline 884986-884991 & Left femur & $\begin{array}{l}\text { - Peri-mortem helical fracture on the postero-medial } \\
\text { aspect of the distal femoral diaphysis }\end{array}$ \\
\hline 884996 & Left femur & $\begin{array}{l}\text { - Peri-mortem impact fracture on the lateral aspect of } \\
\text { the left distal femur }\end{array}$ \\
\hline 8849117 & Right tibia & $\begin{array}{l}\text { - Peri-mortem puncture wound and linear fracture in } \\
\text { the posterior surface of the tibia } \\
\text { - Peri-mortem linear fracture in the lateral aspect of the } \\
\text { proximal tibia } \\
\text { - Peri-mortem ovoid fracture at the distal tibia on the } \\
\text { antero-medial aspect }\end{array}$ \\
\hline
\end{tabular}

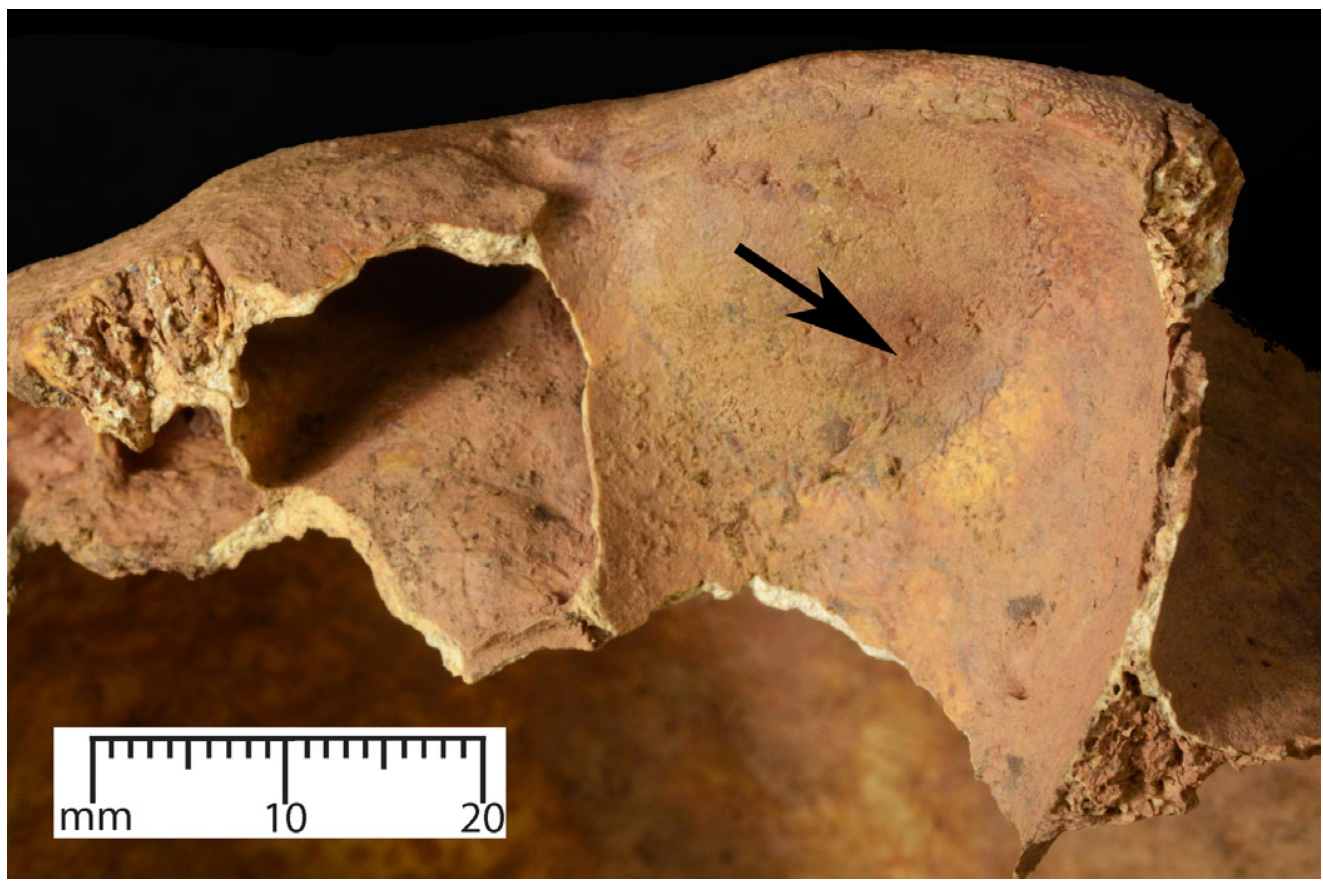

Fig 3. Abnormal bone formation in the left orbit of the cranium. Photograph: authors. 


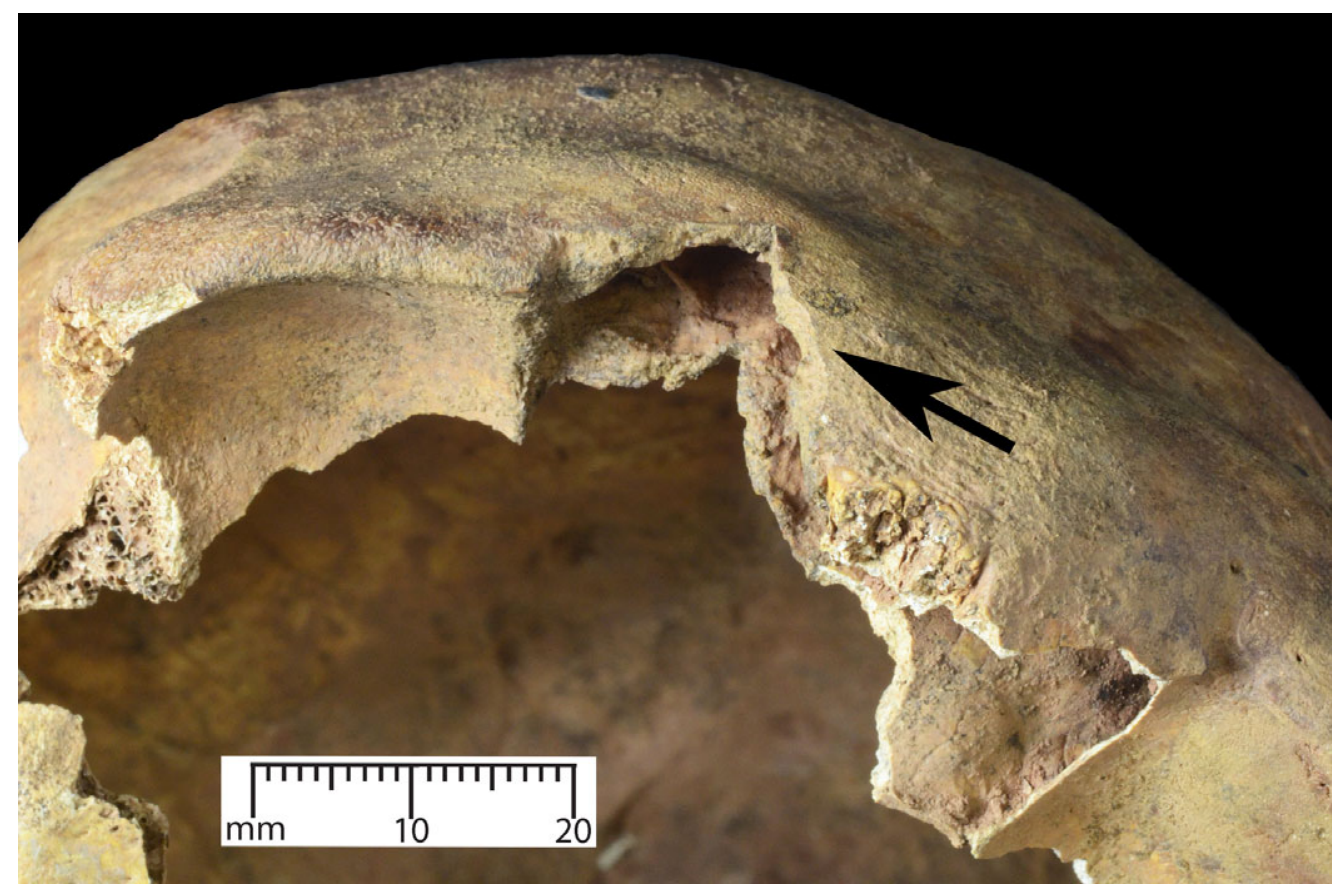

Fig 4. Cranial injury (I): right-angled puncture over the right eye of the cranium. Photograph: authors.

supero-inferiorly. Microscopic examination of the puncture wound with a DinoLite USB microscope revealed a spall on the ectocranial surface of the cranium near the corner of the wound (fig 5). The spall has maximum dimensions of $1.28 \mathrm{~mm}$ supero-inferiorly $\times 0.98 \mathrm{~mm}$ medio-laterally and is associated with a short curving frustrated fracture, $3.2 \mathrm{~mm}$ in length and originating in the superior corner of the puncture wound. The interior edge of the wound shows evidence of pronounced bevelling up to $c 1 \mathrm{~mm}$ across (fig 6).

2. At the posterior of the skull, on the left side of the occipital bone, approximately $33.4 \mathrm{~mm}$ inferior to the lambdoid suture, an exit wound is evident (figs $7-8$ ). This has a maximum width of $24.6 \mathrm{~mm}$ medio-laterally, although its height cannot be ascertained due to fragmentation. Spalling is apparent on the ectocranial, rather than the endocranial, surface and the wound has caused radiating peri-mortem fractures both to the left (as far as the mid-parietal bone) and to the right, although fragmentation in this location means that the extent of this is difficult to ascertain. Irregular bevelling is evident on the endocranial surface. It is possible this bevelling could have been caused by later peri-mortem retraction of a lodged object.

\section{Tibia (identification code: 8849117 (fig 9))}

The right tibia (fig 9) is from a robust individual - probably male - and is well preserved other than the proximal diaphysis and epiphysis which are absent due to post-mortem damage, presumably caused accidently during the excavation. 


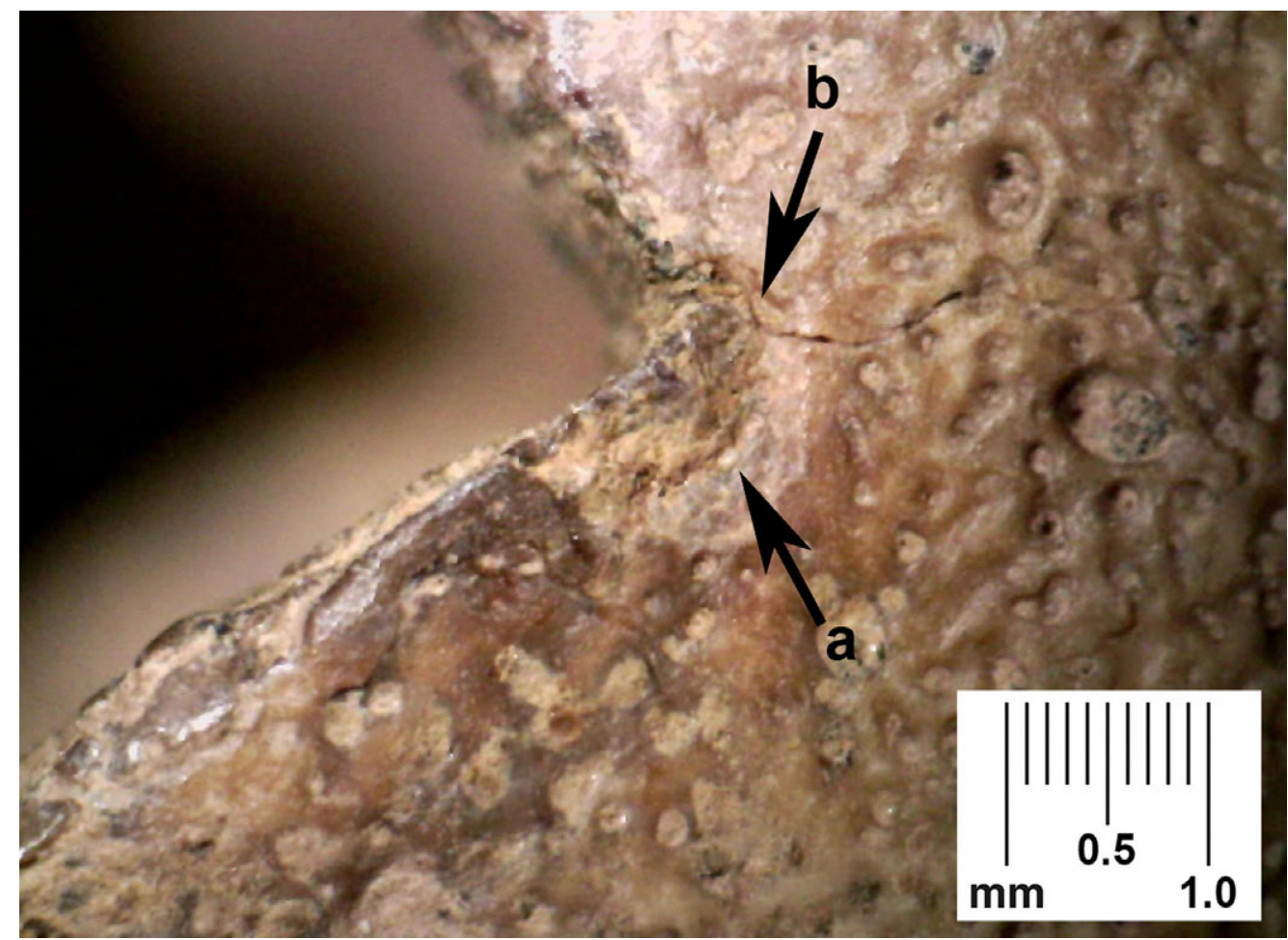

Fig 5. Cranial injury (I): detail of spall on the corner of the cranial puncture wound (ectocranial surface). (a) spall on the ectocranial surface; (b) curving fracture originating in the corner of the puncture wound. Photograph: authors.

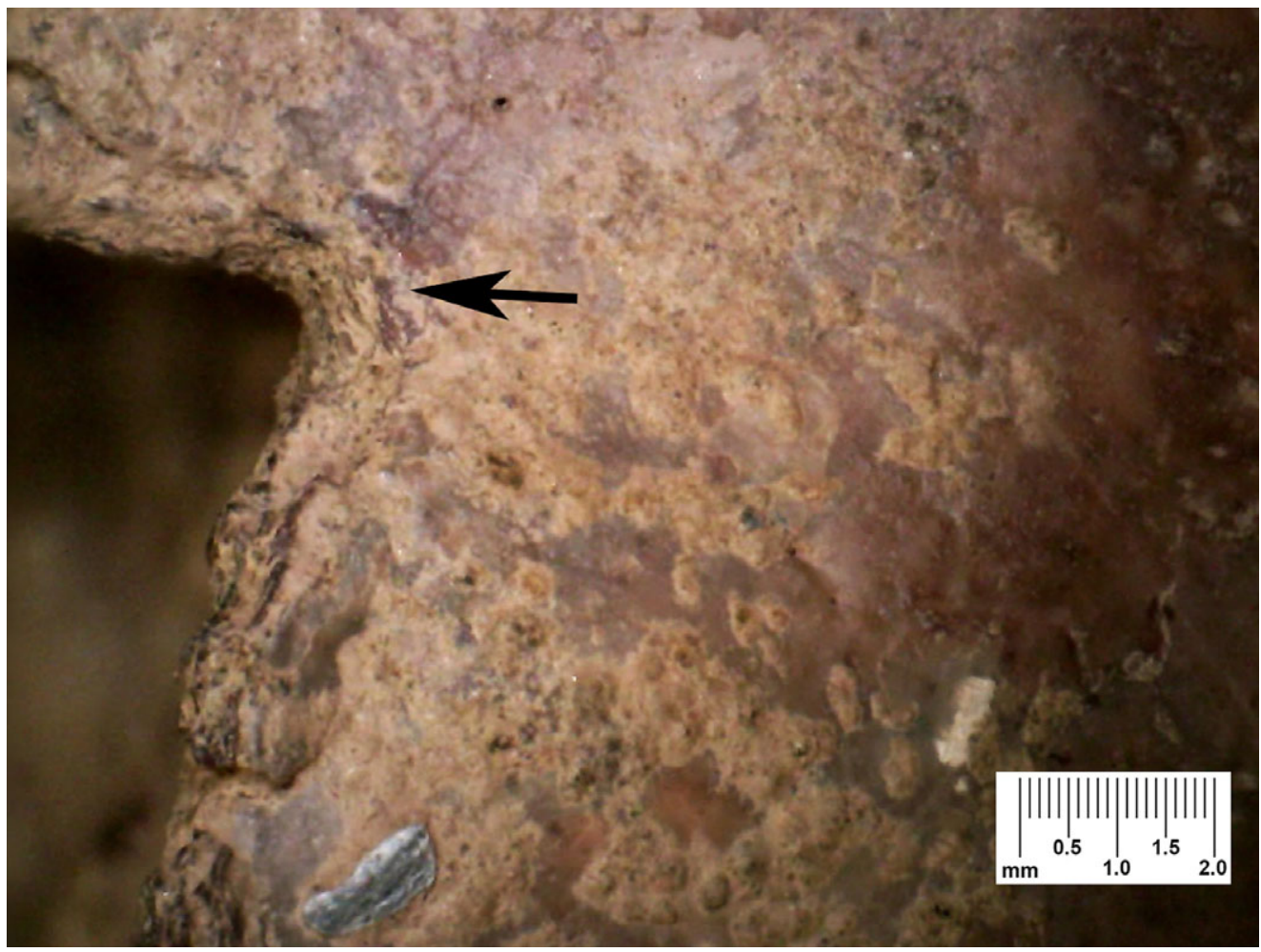

Fig 6. Cranial injury (I): detail of bevelling on the interior of the cranial puncture wound. Photograph: authors. 


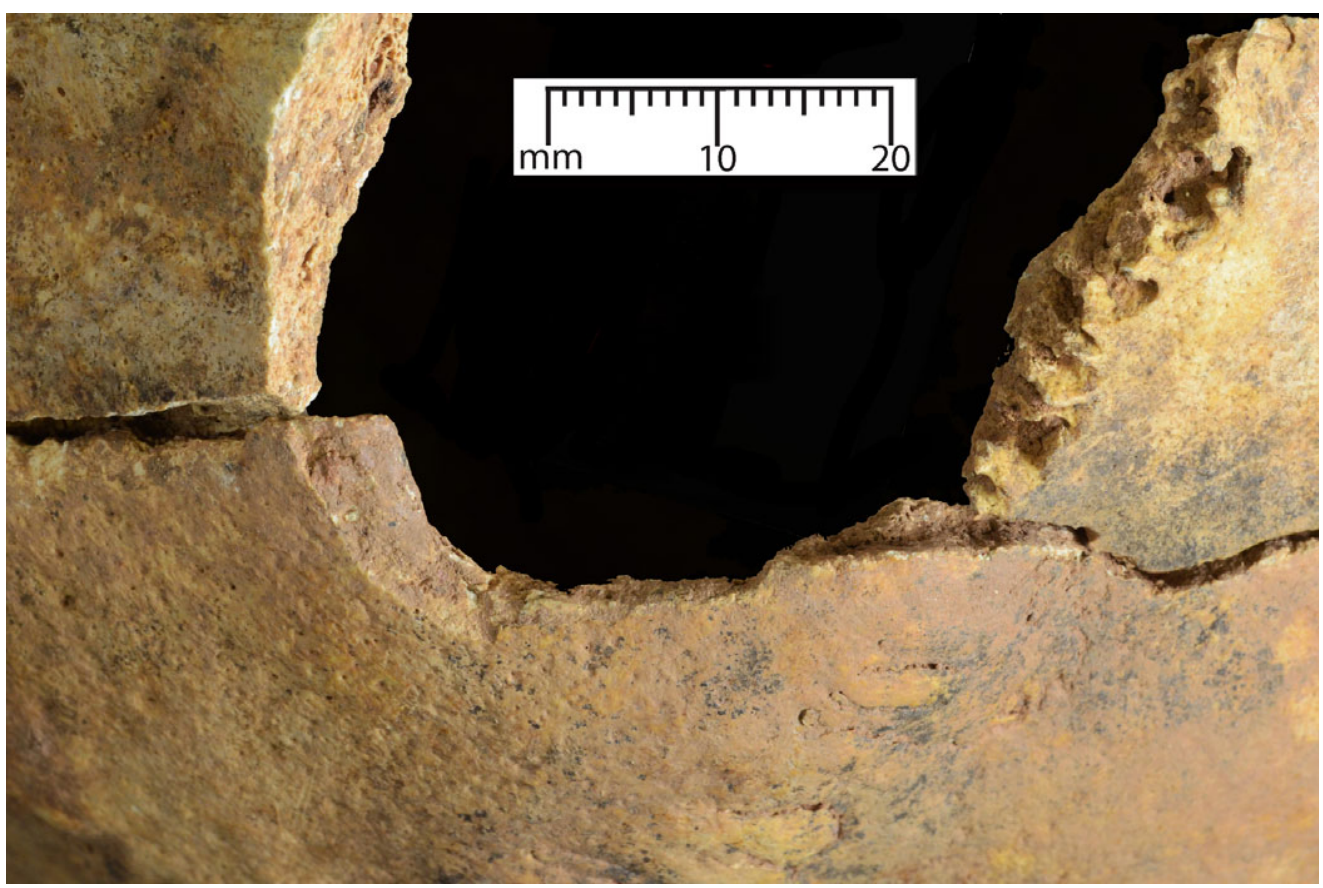

Fig 7. Cranial injury (2): exit wound at the back of the ectocranial surface. Photograph: authors.

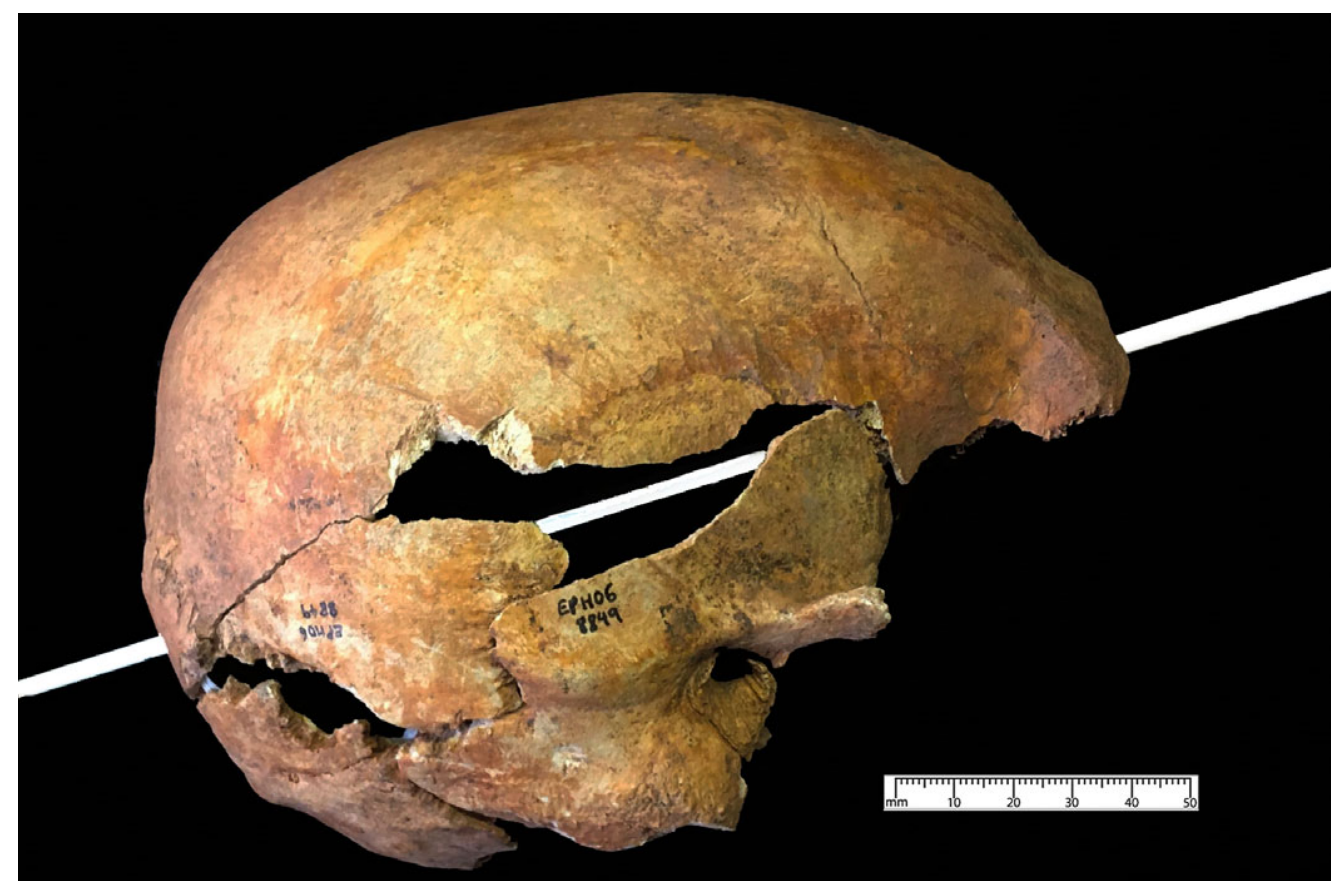

Fig 8. Reconstruction of the angle of entry into the cranium. Photograph: authors. 


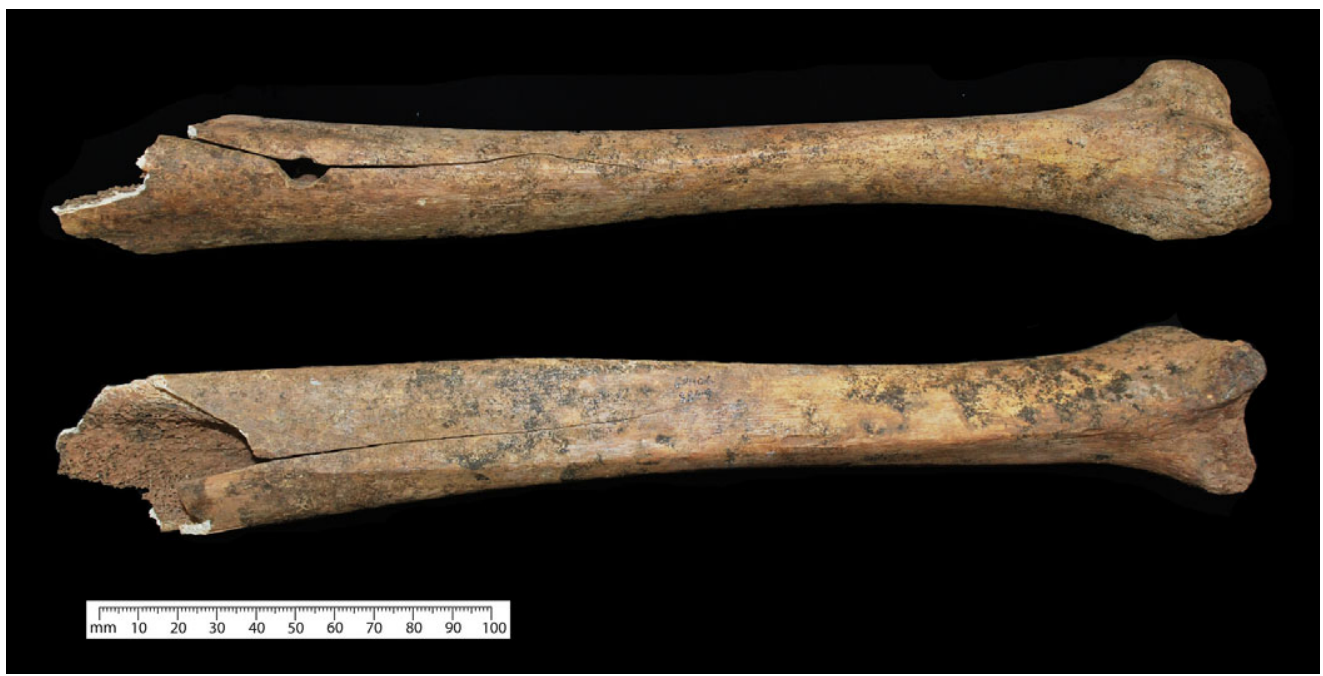

Fig 9. Right tibia: (top) medial aspect; (bottom) lateral aspect. Photograph: authors.

Trauma is evident in three places:

1. On the posterior aspect of the shaft medial to the soleal line (that is, penetrating through the top of the calf), a puncture injury is evident. The shape of the injury is essentially oval, measuring $12.1 \mathrm{~mm}$ supero-inferiorly $\times 7.1 \mathrm{~mm}$ medio-laterally (fig 10), with a peri-mortem linear fracture that radiates proximally and distally from the site of injury, measuring $144 \mathrm{~mm}$ supero-inferiorly (although this is not the maximum length of the radiating fracture as the proximal end of the diaphysis has been broken post-mortem). This fracture line is wider superiorly and narrows as it descends inferiorly the length of the bone. The puncture impact is more pronounced towards the medial side of the fracture, most likely because the lateral side has been displaced laterally by the penetrating object. This would be consistent with dynamic impact from a narrow, tapering object.

2. On the lateral aspect of the diaphysis, deep to $m$. tibialis anterior, is a linear fracture measuring $114 \mathrm{~mm}$ supero-inferiorly (this is not the maximum length of the fracture as the proximal diaphysis is absent). The radiating fracture is wider superiorly and narrows distally, as was the case on the posterior surface, suggesting that the penetrating injury hinged the diaphysis laterally. A small triangular fragment of bone has avulsed from the edge of the linear fracture at the antero-lateral surface of the proximal tibia (fig 11). This is immediately distal to the taphonomic damage.

3. A further ovoid injury affecting the cortical bone at the distal end of the tibia is unrelated to (1) and (2). Located on the antero-medial aspect (that is, just above the ankle on the front of the leg) measuring $c 16 \mathrm{~mm}$ supero-inferiorly by $\times 8 \mathrm{~mm}$ medio-laterally (fig 12). Post-mortem taphonomic damage is apparent at the supero-lateral aspect of the injury.

In all three instances there is no evidence of bone remodelling, indicating that the injuries were sustained peri-mortem. 


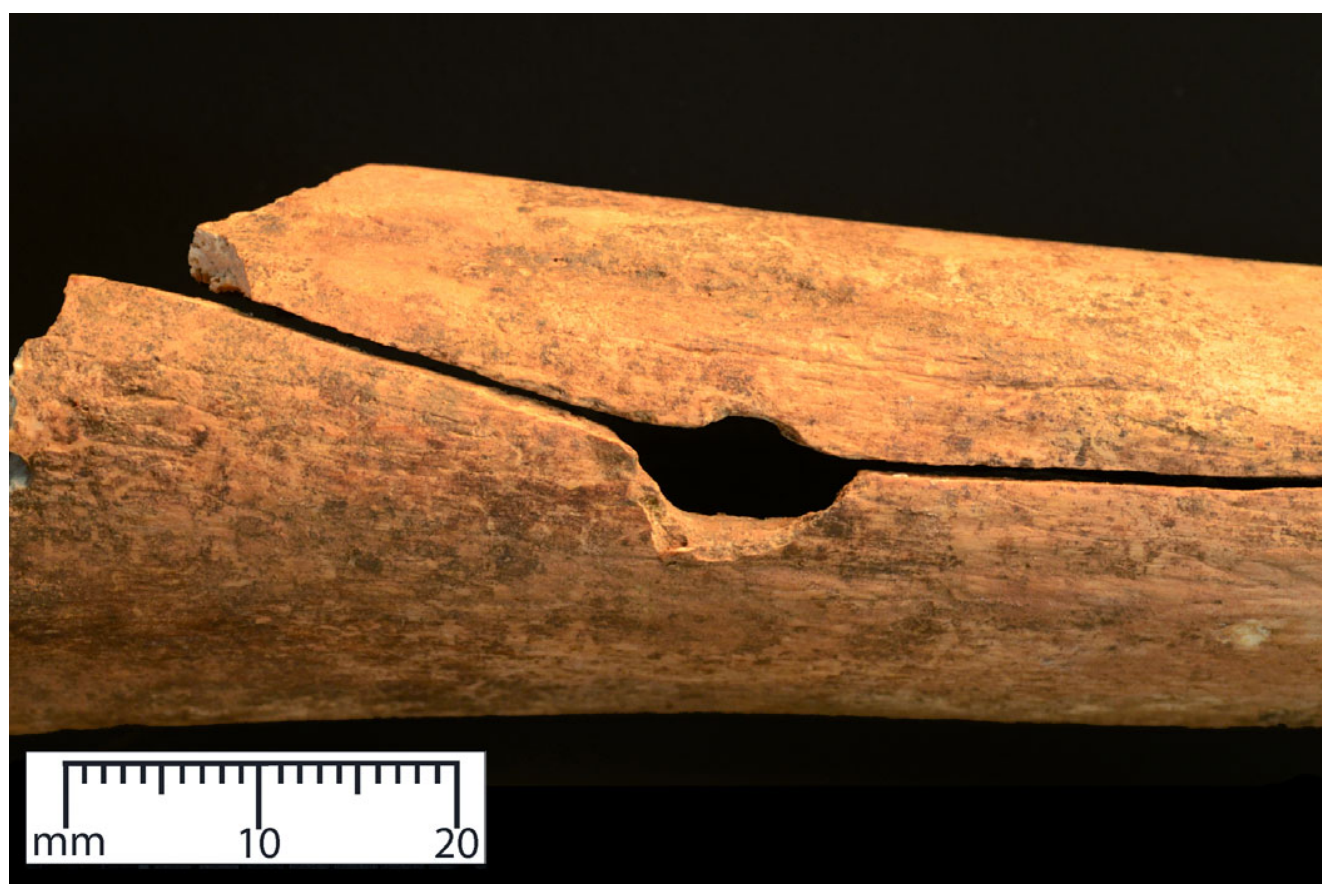

Fig Io. Tibial injury (I): puncture wound and fracture of the tibia. Photograph: authors.

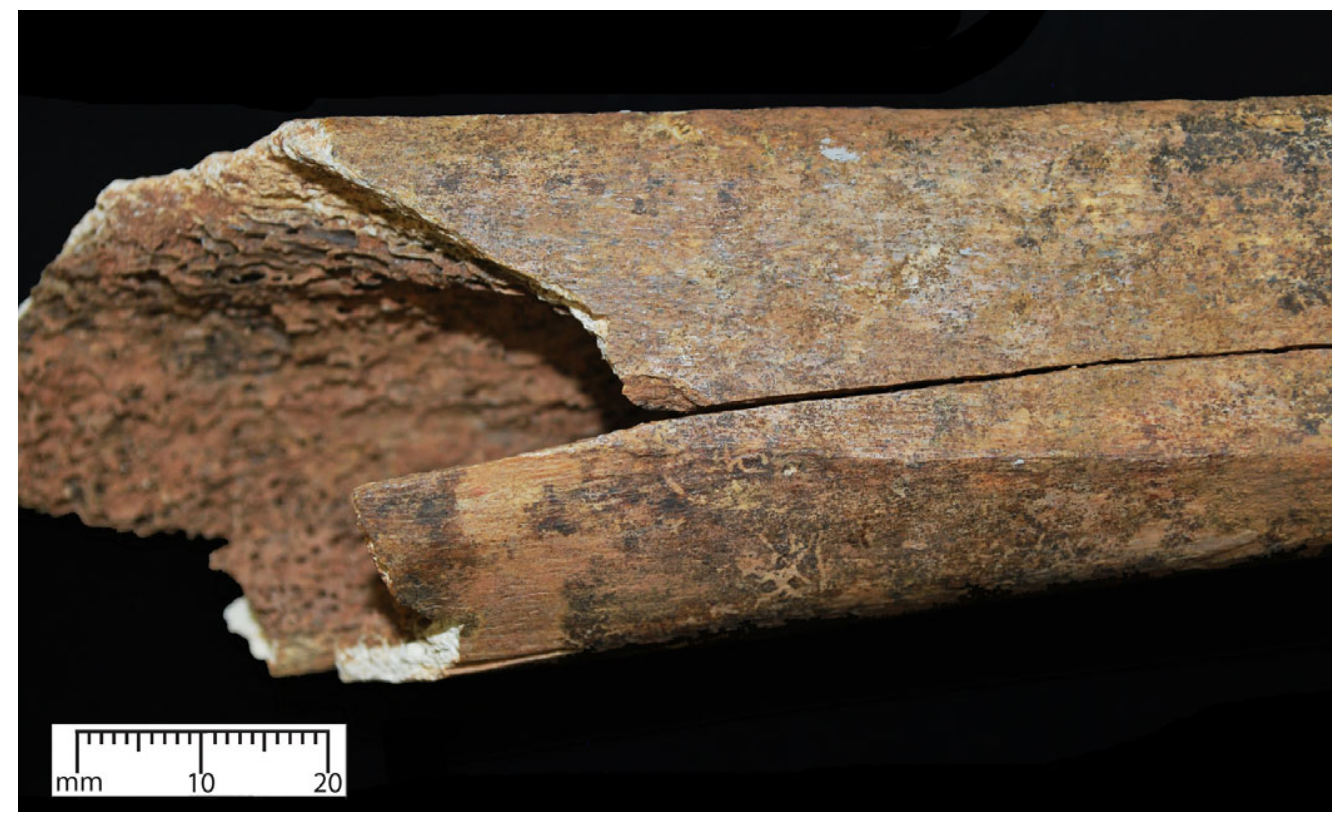

Fig II. Tibial injury (2): small peri-mortem fracture on the lateral surface of the tibia. Photograph: authors. 


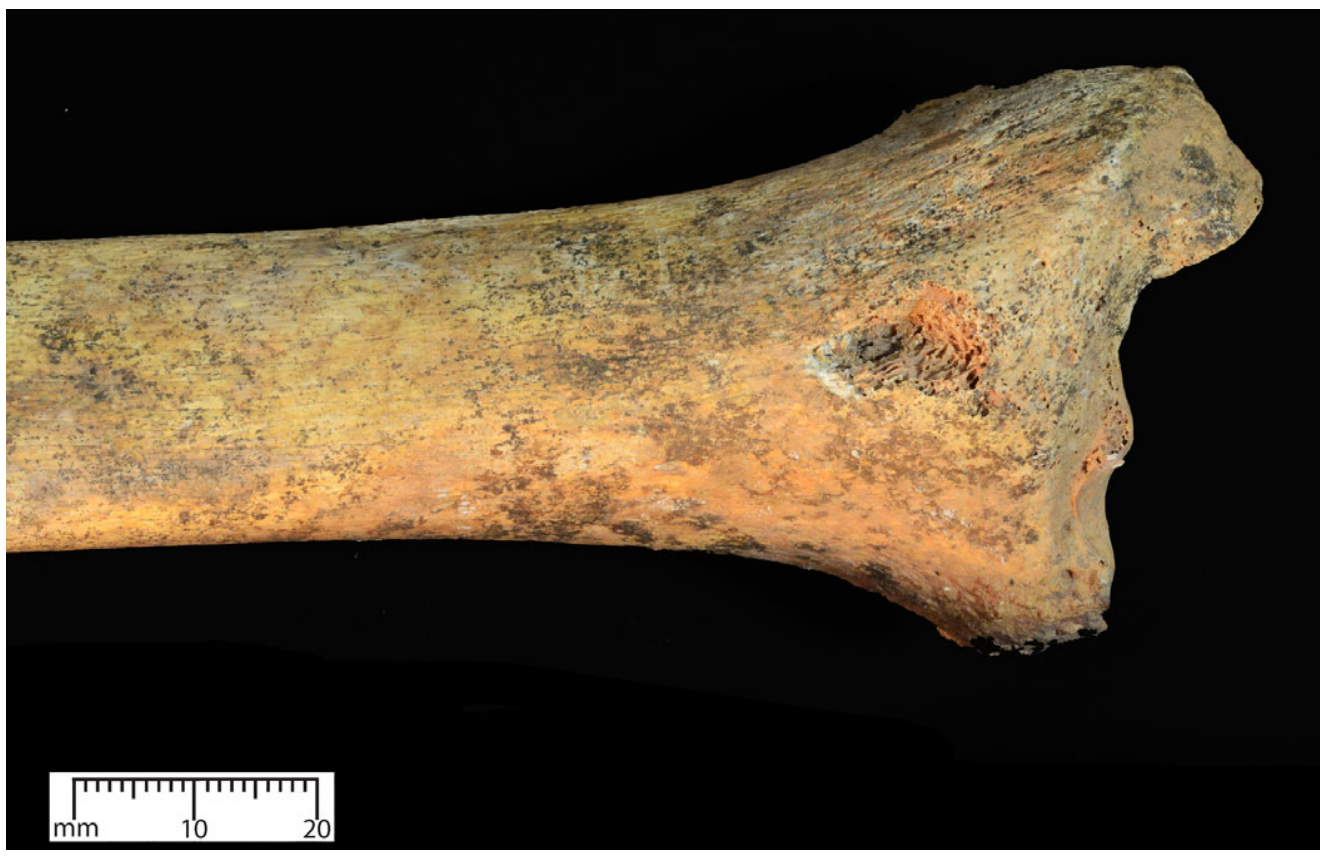

Fig I2. Tibial injury (3): fracture at the distal end of the tibia. Photograph: authors.

Femora (identification codes: 884996 (fig 13) and 884986-884991 (fig 14))

Two femora show evidence of trauma:

1. Femur: 884996 A left distal femoral diaphysis shows a polished groove-like lesion on its lateral aspect with the cortical surface sunken into the distal half of the wound (fig 13). The lesion is oval shaped, running obliquely to the long axis of the bone; wider proximally, with maximum length of $19 \mathrm{~mm}$ and a minimum width of $7 \mathrm{~mm}$, with its pointed end terminating at the linea aspera. A narrow linear groove extends superiorly into the cortical bone measuring $4 \mathrm{~mm} \times 1 \mathrm{~mm}$. Superficial taphonomic damage is evident. The injury is peri-mortem with no evidence of healing apparent. This is an impact lesion likely caused by a penetrating object entering the thigh at downward angle of $c 32^{\circ}$ compared to the long axis of the bone.

2. Femur: 884986-884991 The left femur is missing the distal end of the diaphysis due to post-mortem damage. Post-mortem damage is also evident at the superior aspect of the diaphysis with fragmentation in this location. A traumatic injury (fig 14) is evident on the postero-medial aspect of the distal femoral shaft. Bevelling is evident on the posterior aspect of the injury with damage to the normal trabecular pattern. The distal aspect of the damaged bone is missing post-mortem. The size and shape of the injured area are difficult to measure because of fragmentation, but the approximate dimensions are $c 10 \mathrm{~mm}$ medio-laterally $\times c 8 \mathrm{~mm}$ supero-inferiorly. Propagating helical fractures arise from the superior aspect of the injury radiating supero-laterally around the anterior aspect of the diaphysis (extending for $c 28 \mathrm{~mm}$ ). A linear fracture also radiated distally from the lateral aspect of the defect, the length of the fracture here cannot be determined due 


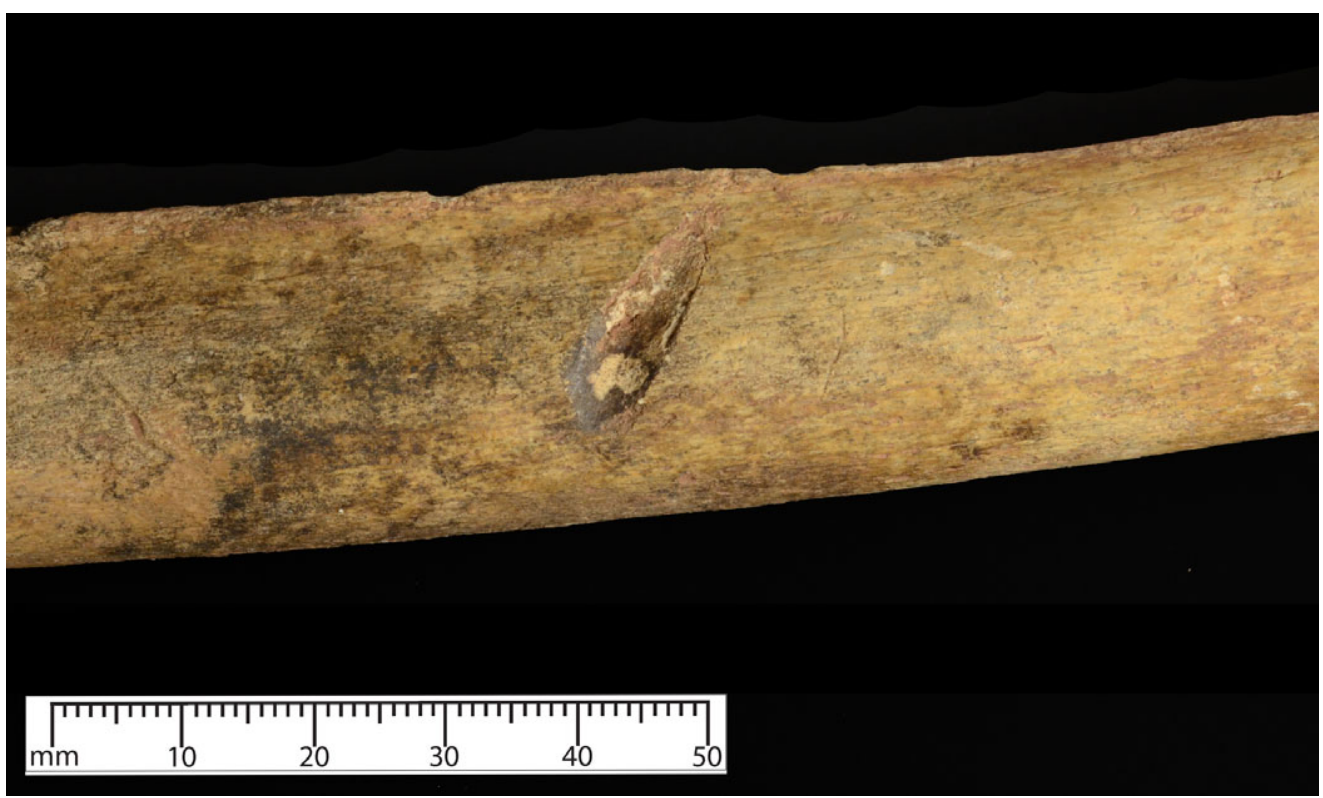

Fig I3. Femoral injury (I): scar on the lateral aspect of the left distal femoral shaft. Photograph: authors.

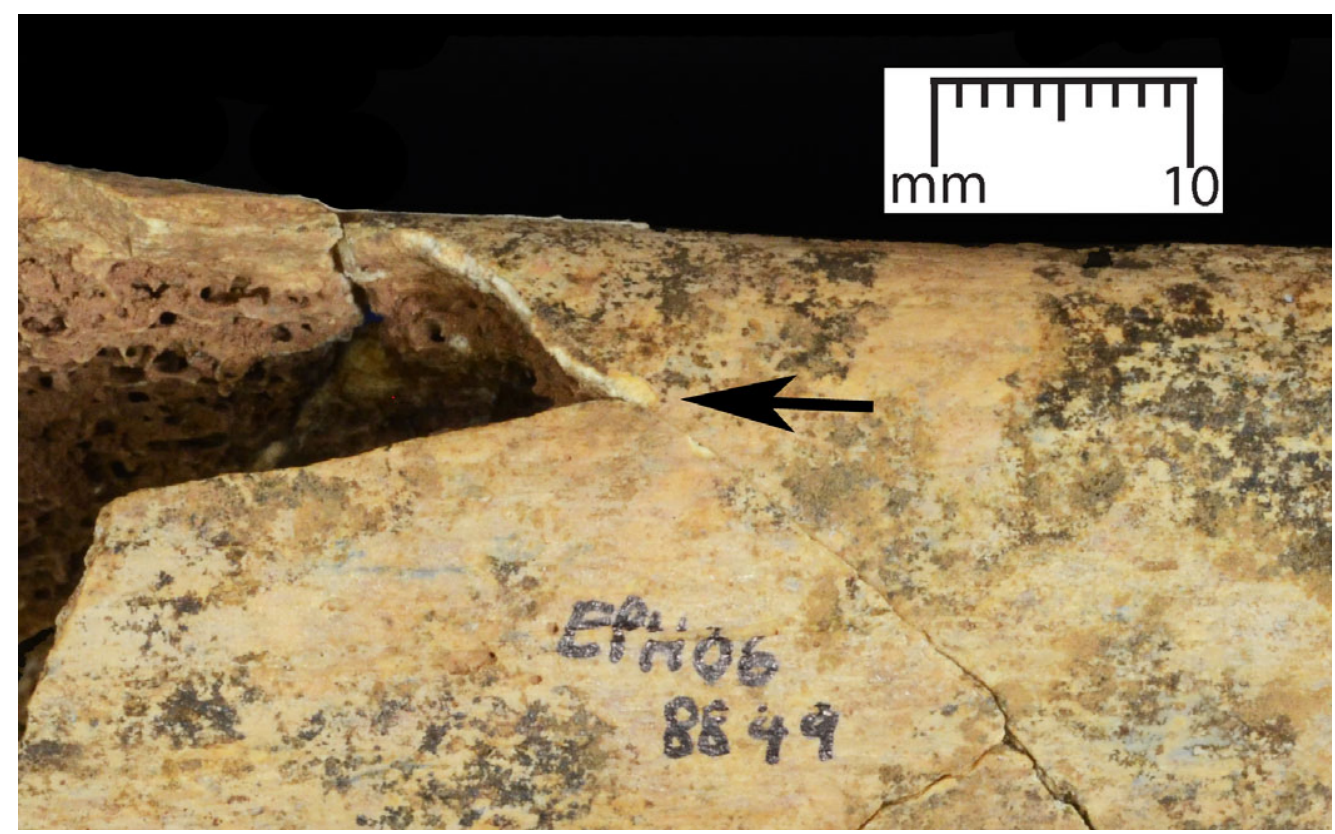

Fig I4. Femoral injury (2): entry trauma causing helical fracture on the left femur. Photograph: authors.

to fragmentation. The entry point is on the medial aspect, suggesting that a penetrating object has entered the lower thigh at an upward angulation (of $c 15^{\circ}$ ) to the long axis of the bone. No evidence of healing is apparent as the injury was peri-mortem in this location. 
The two femora derive from two different individuals. The first (884996) is from a less robust individual than the second (884986-88499I), which is from a particularly robust individual with marked enthesophytes evident at $m$. gluteus medius, m. gleuteus minimus and along the linea aspera.

\section{Humerus (Identification codes: 884936-884937, 8849126 (not illustrated))}

The right humerus has been fragmented by both peri-mortem and post-mortem damage. The humeral head, neck and proximal diaphysis are largely absent as a result of this. Three contiguous fragments of the right humeral diaphysis have peri-mortem helical fractures. Fracturing is evident at the level of the deltoid tuberosity. The peri-mortem fractures in this location indicate that this was a comminuted injury. One limb of the fracture extends supero-medially to the level of taphonomic bone loss. The other limb extends superolaterally, again to the level of the post-mortem bone loss.

\section{Rib (identification code: 884979 (not illustrated))}

Finally, an unsided rib fragment exhibits a simple healed fracture, which is indicative of an injury that occurred during life.

\section{DATING}

The fact that this grave fill (EPH 06 8849) contained disarticulated human remains is not unexpected and is most clearly the result of later graves intercutting and disturbing the contents of earlier graves, as was typical of medieval Christian urban cemeteries of the period. There were similar scatters of disturbed human remains in most other excavated graves from this part of the friary. In terms of dating evidence, the burial $887 \mathrm{I}$ and grave fill 8849 (the context containing the human remains with traumatic injuries) were stratified below a late fifteenth-/early sixteenth-century floor of plain tiles, which in turn was stratified below deposits related to the Dissolution of the friary in the mid-sixteenth century. Given that the human remains in the spread were disarticulated, a considerable period of time must have elapsed between the date of the initial burials and their redeposition, although quite how long is difficult to estimate. On stratigraphical and historical grounds, therefore, the graves within which the human remains were initially deposited could belong to any date after 1232, when the friary was established, but more probably after I259, following its consecration and to take account of a sufficient period of time for the construction of the church nave. They should similarly pre-date the Dissolution.

Given the possibility that the injuries relate to battle casualties, and therefore to a limited potential number of historical events, close dating is desirable. Given this, four AMS (accelerator mass spectrometry) radiocarbon determinations have been obtained from two sample positions (a tooth and a fragment of bone) from the injured cranium; one from the injured tibia (these disarticulated bones were from context 8849); and one from the burial of the middle-aged female EPH 06 8871. These dates revealed that the undisturbed 
burial 887I was indeed the latest in that local sequence, yielding a calibrated date range of $\mathrm{AD} \mathrm{I} 482-\mathrm{I} 645(2 \sigma, \mathrm{UBA}-33486)$. The dates on the disarticulated elements with traumatic injuries were more surprising. The tibia with the puncture wound was dated to $\mathrm{AD}$ I284-I395 (2 $\sigma, \mathrm{UBA}-33485)$ while the cranium with the penetrating injury was dated to $\mathrm{AD}$ I $405-47(2 \sigma, \mathrm{UBA}-33484)$ for the bone sample and AD I399-I454 for the tooth sample $(2 \sigma, \mathrm{UBA}-33487)$. From these dates, it is clear that the disarticulated spread of bone from C. 8849 disturbed and incorporated disarticulated remains from different time periods. The MNI (minimum number of individuals) represented within the context indicated that the remains were those of at least four different individuals; three adults and an adolescent. As the $2 \sigma$ ranges of the tibia and cranium do not overlap, it is intriguing to note that this spread contains strong evidence of traumatic injuries in at least two different individuals, from two different time periods.

\section{DISCUSSION OF THE TRAUMATIC INJURIES}

The assemblage of human remains contains an unusually high number of traumatic injuries. What is the overall pattern of injuries, how were these inflicted, and how does this compare to other known sites? Further, what are the methodological lessons for how we recognise and interpret weapon trauma?

The injuries described above on the cranium as (I) and (2) were most likely caused by the same narrow penetrating object, which entered and exited the skull at a slight downward angle (of approximately $15^{\circ}$ above horizontal, assuming the individual was vertical) (see fig 8). Clearly, this would have led to immediate death. Further, irregular bone spalling may have been produced by retraction of the embedded object.

This puncture wound was most likely made by a narrow implement with a tapering square cross-section that becomes increasingly diamond-shaped towards its point. As the object enters, it initially produces a puncture matching its cross-section but, as it becomes wider, it propagates fractures that displace the lower margins of the wound, creating a wider zone of trauma. As such, the recorded dimensions relate specifically to the puncture wound size and morphology at the point of fracture propagation, rather than necessarily its maximum external dimension.

An alternative hypothesis would be that the supraorbital injury (I) did not lead to penetration through the entire skull, and that the injury below the lambdoid suture (2) was separately the result of blunt force trauma to the back of the head. However, the neatly conchoidal spalling on the ectocranial surface is much more indicative of a projectile exit wound, rather than an injury caused by blunt force trauma. Furthermore, the punctures through supraorbital margin, on the outside of the cranium, and frontal sinus in (I) directly line up with injury (2). This pattern seems consistent with a single event involving a projectile as opposed to two separate injuries.

It is tempting to link the robust femur (884986-88499I) and the robust tibia (8849II7) to suggest that these two bones with injuries may have derived from the same individual (although it cannot be certain that this was the case). The most likely interpretation for the tibial injury is that (I) and (2) represent trauma from a dynamic penetrating injury from a long narrow object. The object appears to have entered towards the back of the individual's calf at a slight upward angle of $c 3^{\circ}$ below horizontal (assuming that the person was standing at the time). 
Other than the orbital haematoma and rib injuries, all the instances of trauma are puncture wounds or impact lesions. Square-, oval-, triangular- and diamond-shaped puncture wounds on medieval skeletal remains can result from blade stabs or penetrations from the beak of a war hammer or the point of a pole-axe. ${ }^{13}$ The wounds discussed in this paper are inconsistent with such weapons, however, because the depth of penetration and exit wounds (particularly in the case of the cranium) could really only have resulted from the impact of a narrow, high velocity projectile - almost certainly identifiable as an arrowhead. Archaeological experiments firing arrows with a medieval-style longbow into cattle scapulae have identified internal bevelling within puncture wounds as especially diagnostic of arrow trauma, ${ }^{\mathrm{I}}$ and this is clearly the case with some of the injuries in question (for example, fig 6).

A possibility that should be considered, but which can be quickly rejected, is that the puncture wounds were created through some sort of post-burial process (that is, either as a by-product of their excavation and redeposition in the medieval period, or during excavation in 2006). Because the fractures' morphology is that of fresh bone, without evidence of healing, this leads to the conclusion that they occurred peri-mortem (that is, around the time of death), but the fact that near-identical traumatic injuries of seemingly unusual character were inflicted on individuals buried several generations apart might prompt the suggestion that they were created when the bones were disinterred and re-buried. Recent post-depositional damage is evident close to some of these injuries, but this is easily recognised by its light colour and fracture morphology. The traumatic lesions identified at Princesshay are clearly peri-mortem because of their associated fracture morphologies, which only occur in fresh bone. ${ }^{15}$ As discussed above, the puncture wounds can therefore only have been created by a penetrating object of very specific form and cross-section with considerable force behind it.

If the traumatic injuries were somehow created in the peri-mortem period, but post-burial, then one possibility is that they were inflicted with a pitchfork-type tool during movement of the bodies. Detailed study of examples of pitchforks dating from between the eleventh and fifteenth century shows that the prongs were of square or rectangular cross-section, broadly comparable to a bodkin-type arrowhead, and were long enough to penetrate the front of a cranium and leave an exit wound at the back. ${ }^{\mathrm{I}}{ }^{6}$ Could a medieval sexton or gravedigger wielding such an implement to move partially decomposed bodies around a cemetery have caused the 'injuries'? If the injuries sustained in the cranial bones were caused by the prongs of a medieval pitchfork, then it would be reasonable to expect additional peri-mortem injuries (caused by different prongs) to be present. Furthermore, the spalling evident on the ectocranial surface is consistent with damage caused by a high velocity projectile, as opposed to a puncture wound caused by a prong. It is conceivable that a medieval pitchfork could be responsible for the tibia, femoral and humeral fractures, but, as each of these display peri-mortem fractures, the bone would have had to have been damaged by a pitchfork shortly after it was initially interred, not long after death.

I3. Novak 2000a, 97-9.

I4. For example, Forsom and Smith 2017, 284.

I5. See Johnson 1985; Villa and Mahieu I99I; Outram et al 2005; Karr and Outram 2012.

I6. See Goodall 20II, IOO-3. 


\section{DEBATING ARROWHEAD TRAUMA IN THE ARCHAEOLOGICAL RECORD}

Medieval arrowheads and crossbow bolt-heads can be confused, but it seems clear that the injuries in question cannot have been caused by crossbows, as the points of penetration are of insufficient size. The injuries described correspond in size to arrowheads rather than crossbow heads, which tend to be larger in size. Heads with internal socket measurements of over $14 \mathrm{~mm}$ are diagnostic of crossbow bolt-heads, while corresponding measurements for military arrowheads are typically 8-1omm, and occasionally up to I $2 \mathrm{~mm} .{ }^{\mathrm{I} 7}$ The shape of the entry wound in the right orbit indicates that the arrowhead must have been square- to diamond-shaped in cross-section and that it penetrated all the way through the cranium to create an exit wound at the occipital. It is likely that while the arrowhead exited the skull the arrow shaft remained lodged and was later retracted back through the front of the head, creating the additional bone spalling as it went. The penetrating injury to the tibia is entirely consistent with penetration by a similar arrow that passed through the flesh and the posterior shaft of the cortical before being stopped by the anterior cortical bone. The injury to the femur is also consistent with a glancing impact from an arrow, though perhaps other types of glancing trauma - possibly from a bladed implement - could also account for this damage.

Within the most current accepted typology of medieval arrowheads from the British Isles (fig 15 ), ${ }^{18}$ this form of arrowhead can be identified as a 'bodkin'-type military point designed to pierce armour, on account of the square-/diamond-shaped nature of the entry wounds. These could not have been created by tanged, hunting or multi-purpose arrowheads, which have flatter, blade-like forms and would have created entirely different (narrow, slit-like) wounds. Experimental archaeology confirms that bodkin-type points result in squarish lesions that match the cross-section of the head. ${ }^{19}$ Bodkin-type points, of wrought iron with a thin steel surface, were mass produced by hand exclusively for military use, in order to counteract the protection afforded by armour. ${ }^{20}$ The closest parallels to the puncture wounds on the Princesshay bones are Jessop types M8, M9 and Mro (see fig I5), which are long and slender, with the maximum width of the point greater than the width of the socket, consistent with the projectiles concerned (see above); these types were commonly in use from the twelfth to the sixteenth century. ${ }^{2 \mathrm{I}}$

A potentially very important implication of the observed pattern and spalling and fracturing associated with the puncture wound in the cranium is that the arrow is likely to have been spinning clockwise when it hit the individual (that is, the spall is located on the right-hand side of the corner of the puncture wound, and the curving fracture emanating from it similarly curves to the right). It is well known that medieval arrows were fletched to enable arrows to spin in order to maximise their stability in flight and accuracy, ${ }^{22}$ but the puncture wound provides evidence - perhaps for the first time - that this arrow at least was fletched to spin clockwise. Notably, gun manufacturers have historically rifled barrels so that bullets spin in the same - clockwise - direction. ${ }^{23}$

I7. Wadge 2008, 4-5; Strickland and Hardy $2011,27$.

18. Jessop 1996; see also Jessop 1997.

19. Forsom and Smith $2017,279$.

20. Jessop I996, I97; Waller 2000, I35; Starley 2005; Strickland and Hardy 20II, 26, 268.

21. Jessop 1996, 194, 199.

22. Strickland and Hardy 2011, 20-5.

23. DiMaio I998, 33-4. 


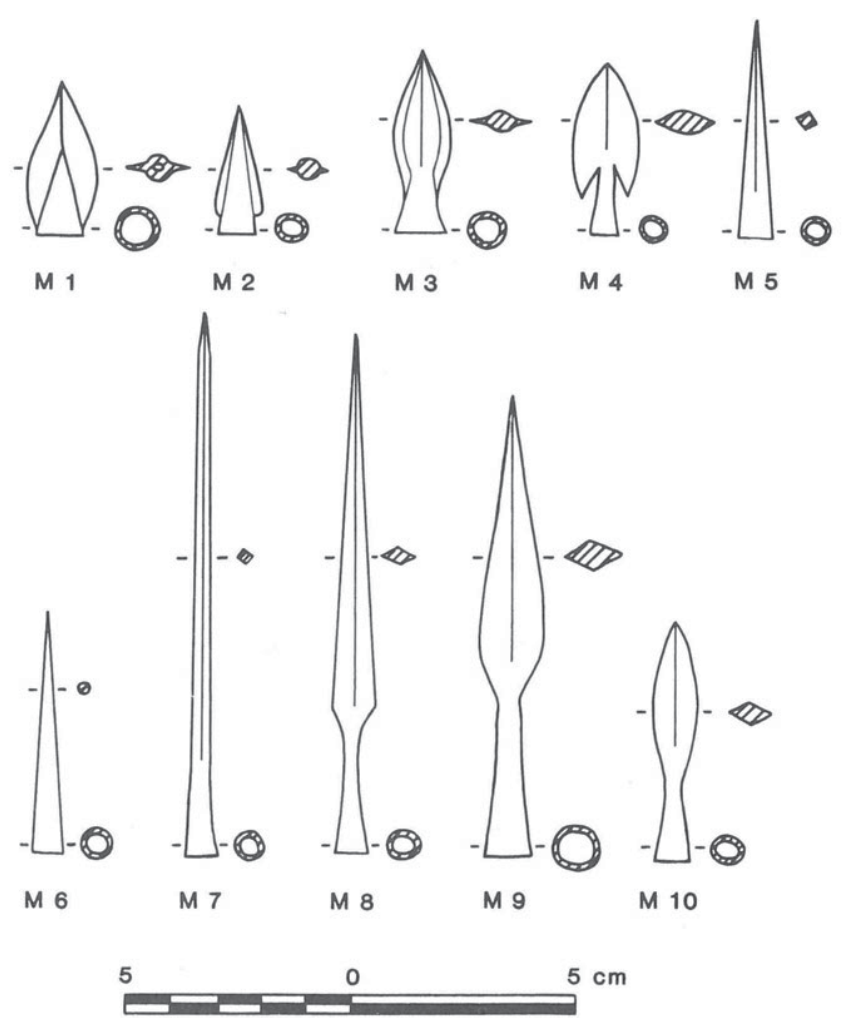

Fig 15. Typology of medieval military arrowheads (after Jessop 1996). Drawing: authors.

That the arrowheads were military points suggests that the assemblage is likely to contain at least one battle casualty, or at least a victim of a field accident or murder perpetrated by individuals with access to military-style equipment. Figure I 6 illustrates the distribution of trauma on the individual(s) represented within the assemblage. While the number of individuals displaying trauma cannot be identified with certainty, it is clearly possible that the cranium and robust femur and tibia come from the same casualty. The wounds occurred peri-mortem and their sequencing can only be speculated upon. As the wound to the skull would clearly have been fatal, one scenario is that this trauma occurred first and that the wounds to the tibia and femur occurred subsequently, when the individual was dead or dying and face down. Although this can only be a matter for speculation, this would probably account for the otherwise odd angles of entry, which are otherwise hard to explain if the individual was standing up, although other possibilities are that they could have been mounted on a horse or standing in an elevated position or on an elevated structure.

The mass grave from the Battle of Towton (I46I), representing a minimum of thirtyseven individuals, produced only two wounds identified as matching projectile weapon profiles. ${ }^{24}$ Both were on skulls: Towton 40 displayed a roughly oval-shaped penetration (I Imm $\times 13.5 \mathrm{~mm})$ from an armour-piercing bodkin-type arrowhead that had penetrated 

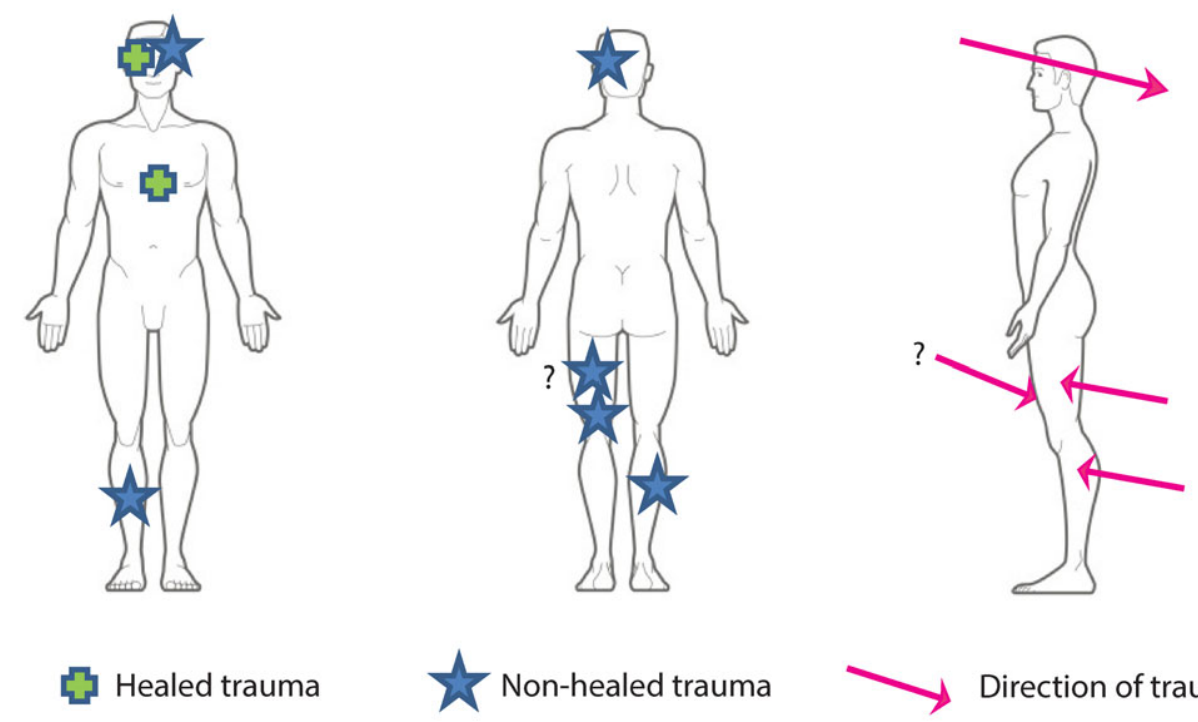

Healed trauma

Non-healed trauma

Direction of trauma

Fig I6. Compound illustration of traumatic injuries on the individual(s). Drawing: authors.

through to its skirt on the left frontal; and Towton $2 \mathrm{I}$ a smaller and more irregular oblong puncture $(8 \mathrm{~mm} \times 2.7 \mathrm{~mm})$ on the occipital from a flesh-piercing arrowhead that had penetrated $c$ Iomm. ${ }^{25} \mathrm{~A}$ reassessment of the Towton evidence suggests, however, that penetrating cranial injuries previously thought to have been caused by arrows were instead caused by daggers, because the shape of the arrowheads recovered from the battlefield are inconsistent with the smaller puncture wounds concerned. ${ }^{26}$

Although the standards of osteoarchaeological analysis with the mass grave at Visby, in Gotland (136I), were not as advanced, due to the site's excavation in the early years of the twentieth century, it is clear that this assemblage shows a particular concentration of arrow wounds in the facial area, with some Io per cent of bodies having been struck in this area by one or more arrows, suggesting that helmets had been removed or visors lifted. ${ }^{27}$

These two case studies relate to mass graves on or near the sites of known and well documented battles. We also have occasional evidence that bodies were transported from the field of conflict to be interred in cemeteries in the 'normal' way, as appears to have been the case with the Princesshay assemblage. No certain examples exist of medieval war graves within the precincts of religious houses, although a pit filled with human bones discovered near the monastic church of St Pancras (in Lewes, East Sussex) in the nineteenth century has been mooted as a possible case in point (conceivably related to the Battle of Lewes in I264), although it might alternatively be a charnel pit. ${ }^{28}$ In York, the cemetery of Fishergate

25. Novak 200ob, 250, 26I.

26. Holst and Sutherland 20I4, I2O-I.

27. Ingelmark 200I; see also Knüsel and Boylston 2000, I79-80.

28. Gilchrist and Sloane 2005, 73 
(a parish church later incorporated into a monastic complex) has yielded skeletons exhibiting battle trauma. At St Andrew's priory, Fishergate (in York), a group of twelve late eleventh-/twelfth-century burials with blade injuries have been identified as the casualties of an unknown battle. ${ }^{29}$ That the same cemetery contains a further seventeen individuals dating between the twelfth and fourteenth centuries with weapons injuries has led to the suggestion that these occurred as a result of trial by combat. ${ }^{30}$

At the site of the twelfth-century Crusader castle of Vadum Iacob (in Israel), within a burial of six adult male battle casualties, three had trauma from bodkin-type arrowheads: one that was still embedded in the ilium bone; one in the cervical vertebrae; and one in the left humerus. ${ }^{3 \mathrm{I}}$ In Lincoln (in England), a male burial among a group of sixteen excavated near the west gate of the castle and dated to $c$ I I 40 displayed traumatic injuries to the skull including a part-healed wound from a heavy weapon such as an axe but also a peri-mortem penetration from a bodkin-type arrowhead and a massive oval wound that seems to have represented the coup de grâce..$^{32}$ Elsewhere in Europe, Kolena et al published the results of the analysis of the osteological remains of a juvenile woman from ninth- to tenth-century Slovakia who had a flat rhomboidal-shaped arrowhead embedded in her second lumbar vertebra - interpreted as a civilian casualty following an attack by Hungarian troops. ${ }^{33}$ Most intriguingly, Faccini et al published two young male skulls from a medieval grave in the crypt of St Peter's cathedral, Bologna (in Italy), which featured traumatic lesions produced peri-mortem: one wound was produced by blunt force trauma, and the other by either an arrowhead type projectile or a nail driven into the skull as a coup de grâce associated with magical-religious rites - perhaps the ritual of 'vampire killing' documented in medieval and early modern contexts! ${ }^{34}$

\section{CONCLUSION: DEBATING THE EFFECTIVENESS OF ARCHERY}

Historians of medieval warfare have debated the efficacy of the English longbow, with one position challenging the traditional view of the bow's invincibility and killing power, 35 and the other reasserting its effectiveness, even against armoured combatants. ${ }^{36}$ Experimental trials with replica medieval longbows have established a scientific basis for understanding the power and effectiveness of the bow, but this body of work has suffered from some assumptions being questioned and aspects of the methodologies being critiqued. ${ }^{37}$ Particularly significant in this context is that the short ranges from which arrows are fired experimentally mean that they are not fully stabilised and spinning in flight, ${ }^{38}$ which has an effect on the injuries sustained. Identification of traumatic injuries caused by arrowheads in

29. Stroud and Kemp I993, I27; see also Knüsel 2013, 267-9.

30. Daniell 200I.

3I. Mitchell et al 2006, I47.

32. Boylston 2000, 373 .

33. Kolena et al 2015 .

34. Facchini et al 2008.

35. De Vries I994, 39-4I, I996, 5-6, I27-8.

36. Rogers 1998 .

37. For example, Jones 1992; Bourke and Whetham 2007; Forsom and Smith 2017.

38. See Bourke and Whetham 2007, 73-4. 
prehistoric contexts is highly unusual in the absence of embedded projectile points, although experimental archaeology shows that lithic projectile points have the capability to penetrate bone more deeply than modern field-tipped arrows. ${ }^{39}$

These debates have continued without reference to any physical evidence for the physical effects of arrow fire on the human body in the past, however. Archaeological evidence has played a very marginal role in the study of how medieval archery was actually practised. Arrowheads have been neglected as a source of evidence for the military uses of the medieval bow despite their fairly common survival. ${ }^{\circ}$ However, no archaeological evidence whatsoever survives for war bows from fourteenth- and fifteenth-century England - the very period that witnessed the 'advent' and then the 'triumph' of the longbow, ${ }^{4 \mathrm{I}}$ and which is celebrated as the golden age of the English archer. It is to this key period in the development of archery that some or all of the traumatic injuries identified in this paper relate. It is not until the mid-sixteenth century that we have surviving examples of English longbows, from the wreck of the Mary Rose, ${ }^{42}$ although one complete twelfth- or thirteenth-century bow (not a longbow) and fragments of six others have been recovered from Waterford in Ireland. 43

Through analysis of an exceptional survival, this paper highlights the critical role that osteological evidence can play in debates about the effectiveness of medieval archery. The analysis provides dramatic evidence for the ability of arrows to create small entry and large exit wounds in the human skull not unlike modern-day gunshot wounds, and to penetrate through long bones. In the medieval world, death caused by an arrow in the eye or the face could have special significance. Clerical writers sometimes saw the injury as a divinely ordained punishment, with the 'arrow in the eye' which may or may not have been sustained by King Harold II on the battlefield of Hastings in Io66 the most famous case in point. ${ }^{44}$ Our study brings into focus the horrific reality of such injuries. Finally, the work highlights the need for the detailed examination and recording of potential arrow trauma, including microscopic examination, in order to ensure that it is not mistaken for other types of injury and post-burial processes.

\section{ACKNOWLEDGEMENTS}

The authors would like to thank Professor Christopher Knüsel (University of Bordeaux), Bob Woosnam-Savage and Henry Yallop (Royal Armouries) and Dr Catherine Hanley for help and advice in identifying the traumatic injuries; Professor Nicholas Orme (University of Exeter) for very useful comments on the historical context; and John Allan for information on the archaeological context. Dr Alex Pryor (University of Exeter) operated the Dino-Lite USB microscope. The authors thank the University of Exeter Archaeology Exploration Fund for supporting the radiocarbon dating.

39. Smith et al 2007, 548-50.

40. Wadge 2008.

4I. Bradbury 1985, chs 6-7.

42. Strickland and Hardy $2011,3-20$.

43. Halpin I997, 56-7.

44. See Dennis 2009. 


\section{BIBLIOGRAPHY}

Bourke, P and Whetham, D 2007. 'A report of the findings of the Defence Academy warbow trials: part I summer 2005', Arms Armour, 4 (I), 53-8I

Boylston, A 2000. 'Evidence for weapon-related trauma in British archaeological samples', in M Cox and S Mays (eds), Human Osteology in Archaeology and Forensic Science, 357-80, Cambridge University Press, Cambridge

Bradbury, J 1985. The Medieval Archer, The Boydell Press, Woodbridge

Daniell, C 200I. 'Battle and trial weapon injury burials of St Andrew's church, Fishergate, York', Medieval Archaeol, 45, 220-6

Dennis, C 2009. 'The strange death of King Harold II: Propaganda and the problem of legitimacy in the aftermath of the Battle of Hastings', Historian, IoI, I4-I8

De Vries, K I994. Medieval Military Technology, Broadview Press, Peterborough, Ontario

De Vries, K 1996. Infantry Warfare in the Early Fourteenth Century, The Boydell Press, Woodbridge

DiMaio, V J M 1998. Practical Aspects of Firearms, Ballistics and Forensic Techniques, 2nd edn, CRC Press, Boca Raton

Facchini, F, Rastelli, E and Belcastro, M G 2008. 'Peri mortem cranial injuries from a medieval grave in Saint Peter's cathedral, Bologna, Italy', Int $\mathcal{f}$ Osteoarchaeol. 18, $42 \mathrm{I}-30$

Ferembach, D, Schwindezky, I and Stoukal, M I980. 'Recommendation for age and sex diagnoses of skeletons', f Hum Evol, 9, 5I7-49

Fiorato, V, Boylston, A and Knüsel, C (eds) 2000. Blood Red Roses: the archaeology of a mass grave from the Battle of Towton $\mathrm{AD}$ I46I, Oxbow, Oxford

Forsom, E and Smith, M J 20I7. 'Getting to the point: an experimental approach to improving the identification of penetrating projectile trauma to bone caused by medieval arrows', F Archaeol Sci: Reports, II, 274-86

Frayer, D W and Martin, D L i997. Troubled Times: violence and warfare in the past, Taylor and Francis, London

Gilchrist, R and Sloane, B 2005. Requiem: the medieval monastic cemetery in Britain, Museum of London Archaeology Service, London

Goodall, I H 201 I. Ironwork in Medieval Britain, Soc Med Arch Monogr 3I, Society for Medieval Archaeology, London

Halpin, A 1997. 'Military archery in medieval Ireland: archaeology and history', in G de Boe (ed), Military Studies in Medieval
Europe: papers of the Medieval Europe Brugge 1997 conference, 5I-60, Instituut voor het Archeologisch Patrimonium, Zellik

Holst, M R and Sutherland, T L 20I4. 'Towton revisited: analysis of the human remains from the Battle of Towton I46I', in S Eickhoff and F Schopper (eds), Schlachtfeld und Massengrab: Spektren Interdisziplinärer Auswertung von Orten der Gewalt, 97-I29, Zossen, Wünsdorf

Ingelmark B E 200I. 'The skeletons', in Thordman et al 200I, 149-209

Jessop, O I996. 'A new typology for the study of medieval arrowheads', Medieval Archaeol, 40, 192-205

Jessop, O I997. 'European iron arrowheads: evidence for their technological development and geographical distribution', in G de Boe and F Verhaeghe (eds), Rural Settlements in Medieval Europe: papers of the Medieval Europe Brugge 1997 conference, 43-9, AAP Rapporten 6, Zellik

Johnson, E 1985. 'Current developments in bone technology', Advs Archaeol Meth Theory, 8, I57-235

Jones, P N I992. 'The metallography and relative effectiveness of arrowheads and armor during the Middle Ages', Mater Charact, 29 (2), I I I-I 7

Karr, L P and Outram, A K 20I2. 'Tracking changes in bone fracture morphology over time: environment, taphonomy and the archaeological record', f Archaeol Sci, 39, 555-9

Klaus, H D 20I4. 'Subadult scurvy in Andean South America: evidence of vitamin C deficiency in the late pre-Hispanic and Colonical Lambayeque Valley, Peru', Int $\mathcal{F}$ Paleopathol, 5, 34-45

Klaus, H D 2017. 'Paleopathological rigor and differential diagnosis: case studies involving terminology, description and diagnostic frameworks for scurvy in skeletal remains', Int $\mathcal{F}$ Paleopathol, 19, 96-I 10

Knüsel, C and Boylston, A 2000. 'How has the Towton project contributed to our knowledge of medieval and later warfare?', in $\mathrm{V}$ Fiorato, A Boylston and C Knüsel (eds), Blood Red Roses: the archaeology of a mass grave from the Battle of Towton AD I46I, I69-88, Oxbow, Oxford

Knüsel, C J 2005. 'The physical evidence of warfare: subtle stigmata?', in M P Pearson and I J N Thorpe (eds), Warfare, Violence and Slavery in Prehistory: proceedings of a 
Prehistoric Society conference at Sheffield University, BAR (Int Ser) 1374, 49-65, Archaeopress, Oxford

Knüsel, C J 2013. 'Courteous knights and cruel avengers: a consideration of the changing social context of medieval warfare from the perspective of human remains', in Knüsel and Smith 2013, 263-82

Knüsel, C J and Smith, M J (eds) 20I3. The Routledge Handbook of the Bioarchaeology of Conflict, Routledge, London

Kolena, B, Luptáková, L, Rendeková, M, Tonková, $M$, Vondráková, $M$ and Hanuliak, M 2015. 'Penetrating arrow injury causing the death of an early medieval woman from the Muzla-Cenkov locality in Slovakia (9th-IOth century CE)', Collegium Antropologicum 39 (3), 50 I-5

Lepine, D and Orme, $\mathrm{N}$ 2003. Death and Memory in Medieval Exeter, Devon and Cornwall Rec Soc (New Ser) 46, Devon and Cornwall Record Society, Exeter

Mitchell, P D, Nagar, Y and Ellenblum, R 2006. 'Weapon injuries in the $\mathrm{I} 2$ th century Crusader garrison of Vadum Iacob Castle, Galilee', Int $\mathcal{F}$ Osteoarchaeol, I6, I45-55

Novak, S 2000a. 'Battle-related trauma', in Fiorato et al 2000, 90-I02

Novak, S 2000b. 'Case studies', in Fiorato et al 2000, 240-68

Outram, A K, Knüsel, C, Harding, A F and Knight, S 2005. 'Understanding complex fragmented assemblages of human and animal remains: a fully integrated approach', f Archaeol Sci, 32 (I2), I699-710

Redfern, R C 20I7. Injury and Trauma in Bioarchaeology: interpreting violence in past lives, Cambridge University Press, Cambridge

Roberts, C and Cox, M 2003. Health and Disease in Britain: from prehistory to the present day, Sutton Publishing, Stroud
Rogers, C J 1998. 'The efficacy of the English longbow: a reply to Kelly DeVries', War Hist, 5, 233-42

Smith, M J, Brickley, M B and Leach, S L 2007. 'Experimental evidence for lithic projectile injuries: improving identification of an under-recognised phenomenon', $\mathcal{F}$ Archaeol Sci, 34, 540-53

Starley, D 2005. 'What's the point? A metallurgical insight into medieval arrowheads', in $\mathrm{R}$ Bork (ed), De Re Metallica: uses of metal in the Middle Ages, AVISTA Stud Hist of Medieval Tech, Sci Art 4, 207-I8, Ashgate Press, Aldershot

Steinmetzer, M, Allan, J and Orme, N forthcoming. Excavations at Princesshay, Exeter, 1997-2006. Part 2: the archaeology and history of the Exeter Blackfriars and Bedford House

Strickland, M and Hardy, R 20II. The Great Warbow: from Hastings to the Mary Rose, Haynes, Sparkford

Stroud, G S and Kemp, R L I993. Cemeteries of the Church and Priory of St Andrew, Fishergate, Archaeol York 12, York Archaeological Trust for Excavation and Research, York

Thordman, B, Norlund, O and Ingelmark, B E (eds) 200I. Armour from the Battle of Visby, I36I, vol 2, Chivalry Bookshelf, Union City (reprinted from Vitterhets Historie och Antikvitets Akademien, Stockholm, I939)

Villa, P and Mahieu, E I99I. 'Breakage patterns of human long bones', F Hum Evol, 2I, 27-48

Wadge, R 2008. 'Medieval arrowheads from Oxfordshire', Oxoniensia, 73, I-I6

Waller, J 2000. 'Archery', in Fiorato et al 2000, I30-6

Weston, D A 20I2. 'Nonspecific infection in paleopathology: interpreting periosteal reactions', in A Grauer (ed), A Companion to Paleopathology, 492-5I2, Wiley-Blackwell, Chichester 